\title{
Working
}

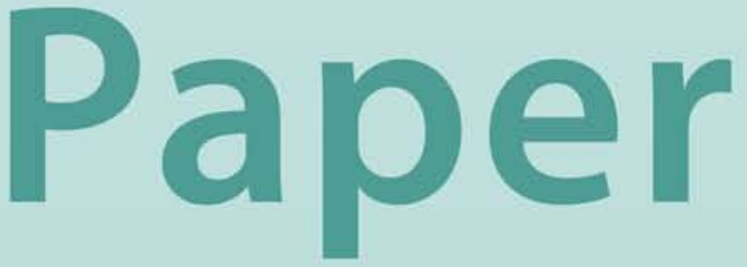




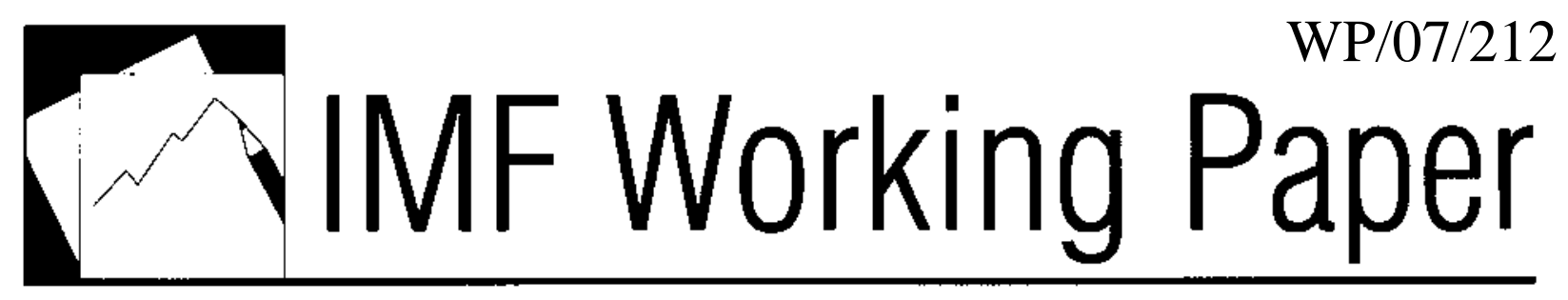

Competitiveness in the CFA Franc Zone

Gustavo Ramirez and

Charalambos G. Tsangarides 


\title{
IMF Working Paper
}

\author{
African Department
}

\section{Competitiveness in the CFA Franc Zone}

\author{
Prepared by Gustavo Ramirez and Charalambos G. Tsangarides ${ }^{1}$ \\ Authorized for distribution by Anne-Marie Gulde
}

August 2007

\begin{abstract}

\section{This Working Paper should not be reported as representing the views of the IMF.} The views expressed in this Working Paper are those of the authors and do not necessarily represent those of the IMF or IMF policy. Working Papers describe research in progress by the authors and are published to elicit comments and to further debate.

This paper reviews the evolution of competitiveness in the CFA franc zone using a proposed comprehensive competitiveness framework. In particular, we examine competitiveness in the WAEMU and CEMAC regions by analyzing the "environment" and "policy" components of competitiveness and their quantifiable determinants, including indicators to measure productivity and labor market conditions, prices and costs, macroeconomic performance, business environment, governance, and technology and infrastructure. Our findings suggest that despite some recent improvements - particularly for the CEMAC — both regions face serious competitiveness challenges when compared to pier groups of countries. In order to become more competitive, raise growth, and improve the quality of life, there is a need for structural reform to improve productivity, reduce factor costs, and create the right business, legal, and political environment to attract economic activity.
\end{abstract}

JEL Classification Numbers: F40, F33, O57, C43.

Keywords: Competitiveness, CFA franc, WAEMU, CEMAC.

Authors’ E-Mail Addresses: gramirez@imf.org; ctsangarides@imf.org.

\footnotetext{
${ }^{1}$ We would like to thank Anne-Marie Gulde-Wolf for her guidance throughout the project. We are also grateful for helpful comments and suggestions received from colleagues in the African Department, particularly the WAEMU and CEMAC members' country teams. All remaining errors are, of course, ours.
} 


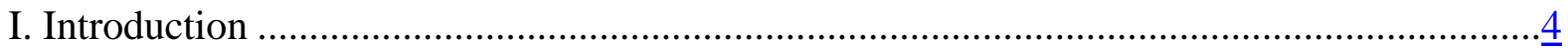

II. The Competitiveness Framework........................................................................... $\underline{5}$

III. Competitiveness Overview: Sustainable Growth and Quality OF Life............................

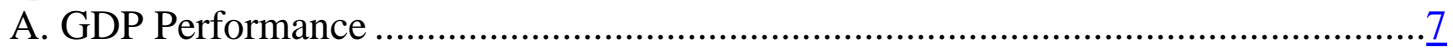

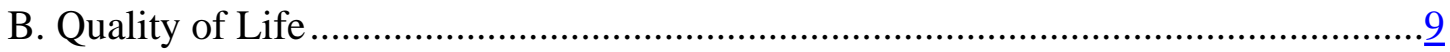

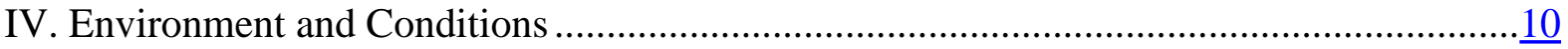

A. Productivity and Labor Markets …...........................................................

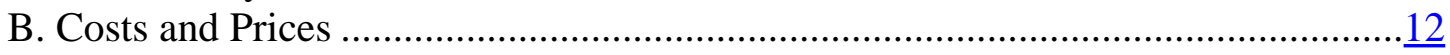

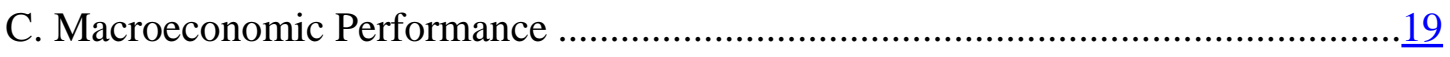

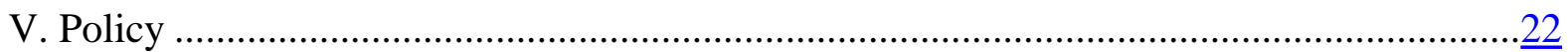

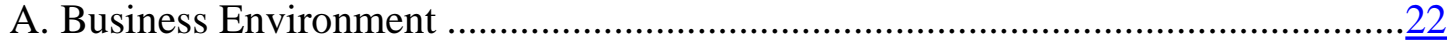

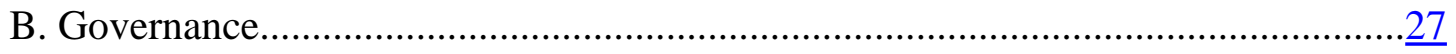

C. Technology and Physical and Human Capital ..................................................

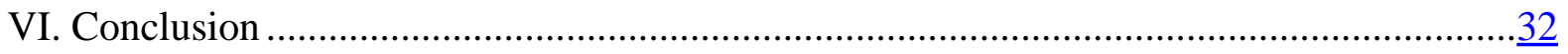

Tables

1. WAEMU and CEMAC: Real Effective Exchange Rate and Components.........................12

2a. CEMAC: Doing Business Indicators, 2006 ...........................................................

2b. WAEMU: Doing Business Indicators, 2006.........................................................

Diagram

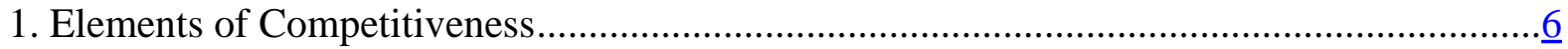

Figures

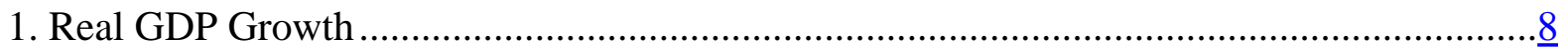

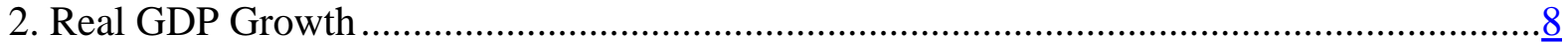

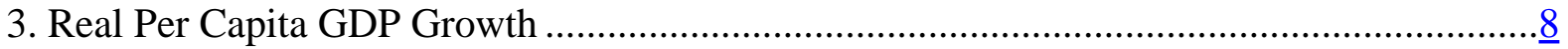

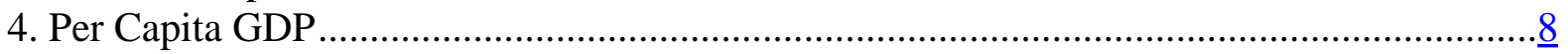

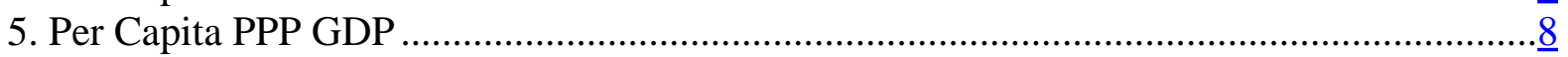

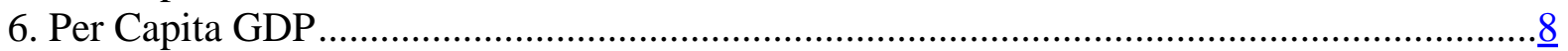

7. 2004 Human Development Index …...........................................................................

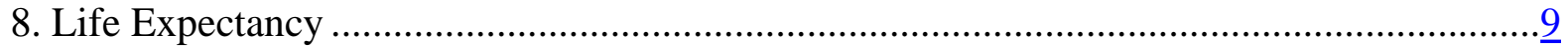

9. GINI Coefficient .............................................................................................. 10

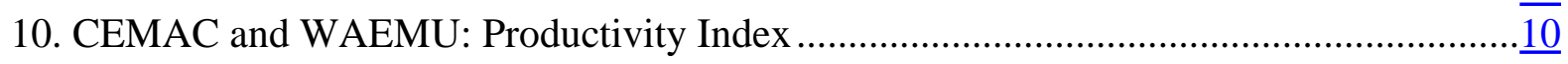

11. Demographics and Labor Market ….....................................................................

12a. CEMAC: Exchange Rates and Relative Prices .............................................................. 
12b. WAEMU: Exchange Rates and Relative Prices ………………………...........................14

13a. CEMAC: Real Effective Rates of Member Countries .......................................................14

13b. WAEMU: Real Effective Exchange Rates of Member Countries....................................14

14a. CEMAC: Internal Real Exchange Rate vs. Real Effective Exchange Rate.......................14

14b. WAEMU: Internal Real Exchange Rates vs. Real Effective Exchange Rate....................14

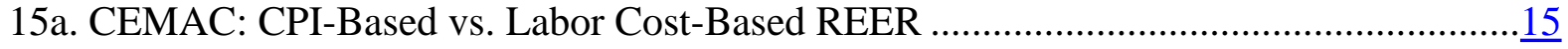

15b. WAEMU: CPI-Based vs. Labor Cost-Based REER .....................................................15

16a. CEMAC: CPI vs. Tertiary Deflator based REER …………………............................... 16

16b. WAEMU: CPI vs. Tetiary Deflator-Based REER …………............................................

17a. CEMAC: Nominal Effective Exchange Rate................................................................. 16

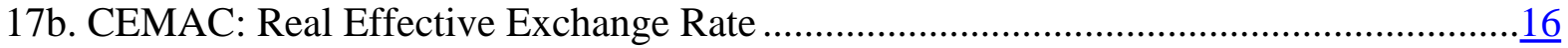

18a. WAEMU: Nominal Effective Exchange Rate ………….............................................

18b. WAEMU: Real Effective Exchange Rate......................................................................

19a. CEMAC: Real Wage Index......................................................................................

19b. WAEMU: Real Wage Index .......................................................................................

20a. CEMAC: Ration of Exports to Selected Groups’ Total Imports .....................................20

20b. WAEMU: Ratio of Exports to Selected Groups' Total Imports (In percent) ....................20

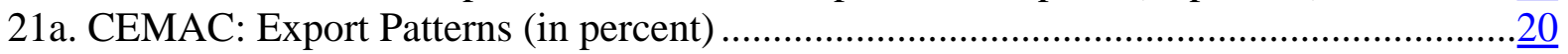

21b. WAEMU: Export Patterns (in percent)..........................................................................

22. Exports of Goods and Services (Percent of GDP) ...........................................................

23. Foreign Direct Investment (US\$, billions)....................................................................21

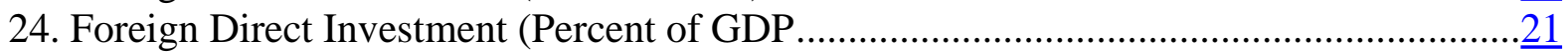

25. WAEMU: Export Performance by Product, 2000-05.........................................................22

26a. CEMAC: Terms of Trade, Real Oil Price and Exchange Rates ……………………….....23

26b. WAEMU: Terms of Trade, Export Prices and Exchange Rates .......................................23

27a. CEMAC: Profitability Indicator Export Price Index/Wage Index ....................................23

27b. WAEMU: Profitability Indicators.................................................................................23

28. CEMAC: Profitability Indicator Export Price Index/Tetriary GDP Deflator ......................23

29. CEMAC and WAEMU: Doing Business Indictors, 2006 .................................................26

30. Governance Indicators, 2005 ....................................................................................

31. Infrastructure and Technology Indicators .................................................................

32. Human Capital Indicators .........................................................................................32

33. CEMAC and WAEMU Relative to Sub-Saharan Africa (Percent of Total SSA) ................33

34. CEMAC and WAEMU Relative to Low and Middle Income Countries .............................33

Appendices

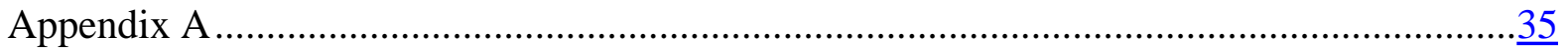

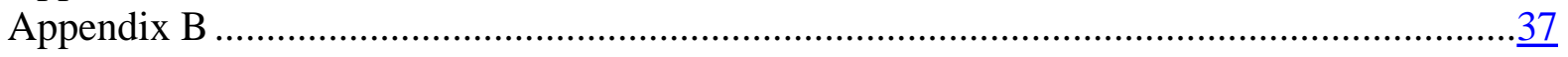

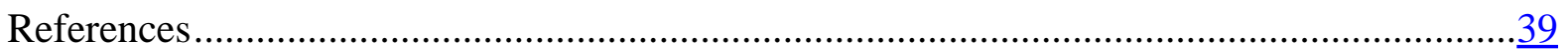




\section{INTRODUCTION}

The 1994 devaluation of the CFA franc was a result of a prolonged deterioration of the terms of trade of the countries of the CFA franc zone, a steep rise in the labor costs of those countries, and a nominal appreciation of the French franc against the U.S. dollar, all of which resulted in an overvalued exchange rate. ${ }^{2}$ The devaluation was instrumental in making CEMAC and WAEMU countries more competitive, and, reinforced by prudent macro policies and structural reforms, helped GDP return to positive growth rates. ${ }^{3}$ This experience has shown that maintaining the fixed exchange rate regime in the CFA franc region requires careful attention to competitiveness and suggests that an assessment of whether the competitiveness gains since the devaluation have been preserved or eroded is warranted.

Generally, competitiveness can be defined as the ability of a country to operate efficiently and productively in relation to other countries while keeping living standards for its citizens high. From a macroeconomic perspective, competitiveness can be viewed as the degree to which a nation can produce goods and services that meet the test of international markets while simultaneously expanding the real incomes of its people over the long term under free trade and fair market conditions (OECD, 1992). At the microeconomic level, competitiveness is the capacity to sell products profitably. To be competitive, a firm-and by extension, a countrymust be able to charge lower prices or offer products of better quality (or with better service) than its competitors (Cockburn et al., 1998).

Using a comprehensive competitiveness framework we review the evolution of competitiveness in the CEMAC and WAEMU regions and benchmark their performance against other countries and comparator groups. Our main findings are as follows. First, the evidence of the evolution of competitiveness in the two regions suggests that there are some areas where competitiveness has improved (particularly export profitability and market share in CEMAC driven by oil market developments) but others where competitiveness has worsened (including, for both regions, real effective exchange rate appreciation and poor scores on cost of doing business and governance). Second, there are serious competitiveness gaps when CEMAC and WAEMU are compared with their peer groups of countries, particularly in the areas of business environment, governance, and human capital. Finally, in order to overcome competitiveness challenges in the regions there is a need for structural reform policies in both regions to boost productivity, reduce excessive factor costs, diversify the base of production, and create the conditions to attract higher domestic and foreign private investment in all sectors of economic activity.

\footnotetext{
${ }^{2}$ A fixed exchange rate for the CFA franc (CFAF) was adopted by the CFA franc zone countries in 1948. The franc zone countries include the eight members of the West African Economic and Monetary Union (WAEMU) and the six members of the Central African Economic and Monetary Union (CEMAC).

${ }^{3}$ The 50 percent devaluation in January 1994 was the only change in the exchange rate peg. Since the introduction of the euro in 1999, the CFAF has been pegged to the euro at CFAF 655.957 per $€ 1$.
} 
The rest of the paper is organized as follows. Section II presents the thinking about competitiveness and proposes our competitiveness framework. Section III reviews progress in achieving sustainable growth and improvements in the quality of life in CEMAC and WAEMU. Section IV presents the environment and conditions affecting competitiveness. Section V presents policy inputs affecting competitiveness. Section VI concludes and provides policy implications.

\section{THE COMPETITIVENESS FrAMEWORK}

Countries are increasingly evaluating their competitiveness in global markets, and international competitiveness comparisons are conducted yearly. ${ }^{4}$ National competitiveness is particularly important for small open economies aiming to provide people with the opportunity to improve their living standards and quality of life, by providing employment and raising incomes through productivity gains. While productivity gains are necessary, the process of raising productivity may differ across countries.

Competitiveness can be analyzed on many dimensions. The World Economic Forum's annual Global Competitiveness Report (GCR) separates countries by stage: factor-driven, efficiencydriven, or innovation-driven. Countries in the factor-driven stage of development have four main concerns: well-functioning public and private institutions, appropriate infrastructure, a stable macroeconomic framework, and good health and primary education. On the other hand, the four main factors the World Competitiveness Yearbook (WCY) uses in analyzing countries are economic performance, government efficiency, business efficiency, and infrastructure. Finally, the competitiveness pyramid of the Irish National Competitiveness Council (NCC) distinguishes between the "inputs" to national competitiveness - over which policymakers can have greater control—and the "essential conditions."

The common theme among all these analyses is that competitiveness is about identifying the elements necessary to ensure sustainable growth and improve living standards. Therefore, building on the Ireland NCC approach, we view competitiveness as consisting of two interlinked components or conditions, "environment" and "policy." 5 The environment component includes measures of costs, prices, exchange rates, and wages and their impact on the ability of the country to export enough goods and services to pay for its import requirements and maintain full employment. The policy component includes factors that contribute to better business performance through innovation and productivity, such as the business environment,

\footnotetext{
${ }^{4}$ Some countries, among them like the United States, Ireland, Croatia, Greece, the Philippines, and Tunisia maintain advisory bodies or special government agencies that handle competitiveness issues. Yearly competitiveness surveys are conducted by the World Economic Forum (Global Competitiveness Report); the International Management Development Institute (World Competitiveness Yearbook); and the World Bank (Doing Business).

${ }^{5}$ Models used in the Global Competitiveness Report and World Competitiveness Yearbook can, in a sense, be "embedded" in the Ireland model, which we consider more comprehensive for our analysis.
} 
governance, and physical and human capital. There are also useful and important links between the two components. For example, the determinants of the environment-namely, prices and costs, macroeconomic performance, and productivity and labor markets-are the conditions of competitiveness that good policies create. Similarly, policies are both responses to and results of the current environment. Diagram 1 summarizes the factors that affect national competitiveness and presents growth and quality of life as the ultimate goals of competitiveness.

\section{Diagram 1. Elements of Competitiveness}

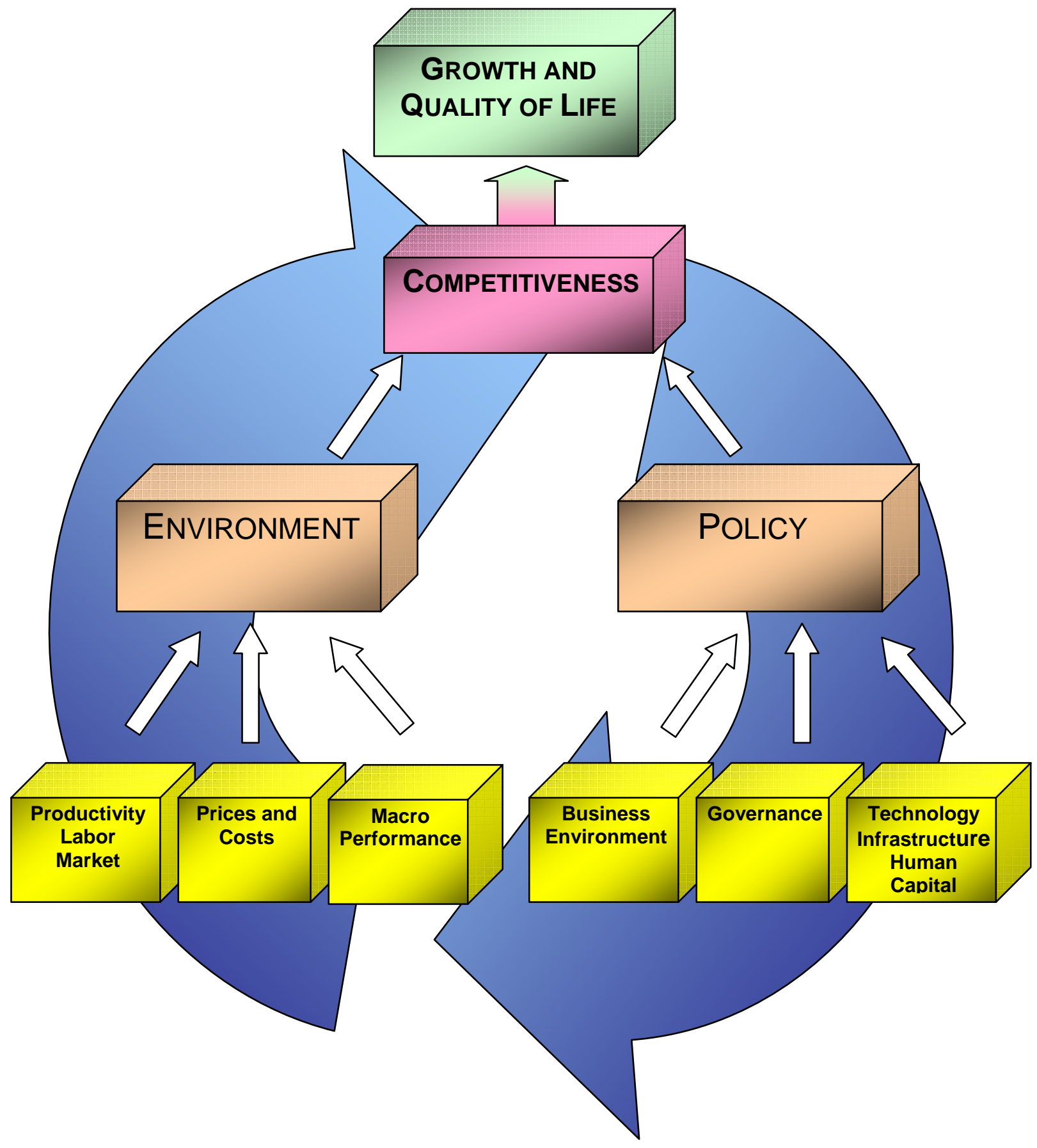


Our analysis traces sequentially environment and policy factors and their determinants to provide a comprehensive story of competitiveness in the CFA franc zone. Our work is complementary to other competitiveness reports on Africa-notably the 2007 World Economic Forum's Africa Competitiveness Report-but at the same time, more comprehensive in its coverage of all fourteen countries of the CFA franc zone and more focused on the characteristics of the WAEMU and CEMAC regions. ${ }^{6}$ Our work differs from the on-going work of the IMF's Policy Development and Review (PDR) Department to develop a template to assess competitiveness and real exchange rate misalignments in low-income countries. We avoid generalizing competitiveness indicators in some form of a metric to assess competitiveness. Rather, to avoid synthesizing results from a variety of indicators, we try to capture a more "global” view of the two regions' competitiveness by comparing how each region fares vis-à-vis the other and the comparator groups.

Before proceeding, it is useful to recognize the data limitations associated with our analysis, as it is the case in many developing country competitiveness analyses. ${ }^{7}$ While these limitations do exist, nevertheless, we believe that they do not reduce the usefulness of our analysis. The multiplicity of competitiveness indicators examined allows the flexibility to look at a more comprehensive picture of competitiveness and reduces the errors that may result from any data limitations.

\section{COMPETITIVENESS OVERVIEW: SUSTAINABLE GROWTH AND QUALITY OF LifE}

\section{A. GDP Performance}

Growth since the devaluation has varied within the CFA franc zone and has been uneven between WAEMU and CEMAC. It has been linked to external price exchange rate developments, as well as the structural characteristics of economies in the regions. Oil market developments-including variations in world oil prices and country-specific positions in the life cycle of oil production - have dominated the CEMAC economies. ${ }^{8}$ Since 1994, real GDP growth in the CEMAC averaged about 5 percent of GDP (with a pronounced drop in 1999 as oil prices plunged) while in the WAEMU, growth has been lower and more volatile, averaging about 4 percent. Relative to the averages for sub-Saharan Africa (SSA), real per capita growth has been strong. Real growth in both regions has exceeded growth in Latin America and OECD, and in the CEMAC growth has exceeded that of emerging Asia and for 2001-06 was almost

\footnotetext{
${ }^{6}$ The 2007 Africa Competitiveness Report covers only 5 of the 16 countries of the WAEMU and CEMAC regions.

${ }^{7}$ In fact, many competitiveness analyses exclude developing counties due to data availability and reliability issues. In other cases, as for example in the 2007 Global Competitiveness Report (page xxv), the reader is cautioned that for some countries survey data "have high within-country variance; until the reliability of survey responses improves with future educational efforts and improved sampling in these countries, their rankings should be interpreted with caution.”

${ }^{8}$ Of the six CEMAC members, only the Central African Republic does not produce oil. Petroleum constitutes the bulk of the region's export receipts and more than half its budgetary revenue.
} 
double the SSA average (Figures 1 and 2). However, real growth in per capita terms was not as favorable for either region, with WAEMU growing at lower than SSA rates and CEMAC just about the SSA rates (Figure 3). Disparities between WAEMU and CEMAC result from higher population growth rates in WAEMU and higher growth in the CEMAC due to oil market developments.
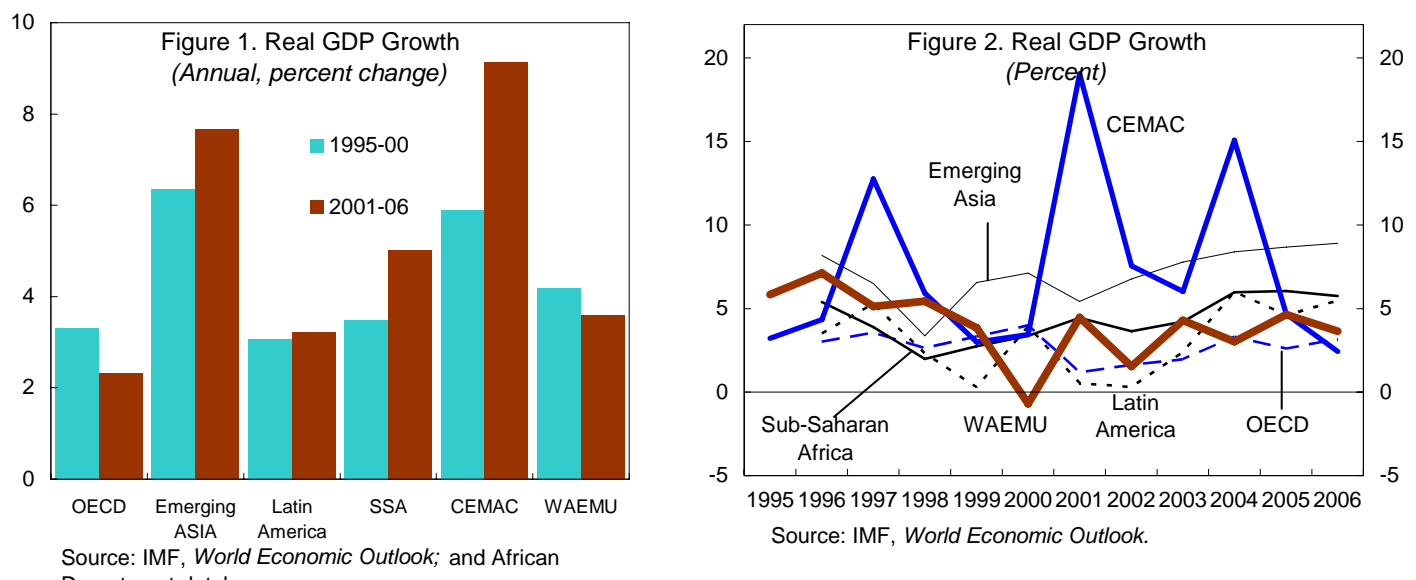
Department database.
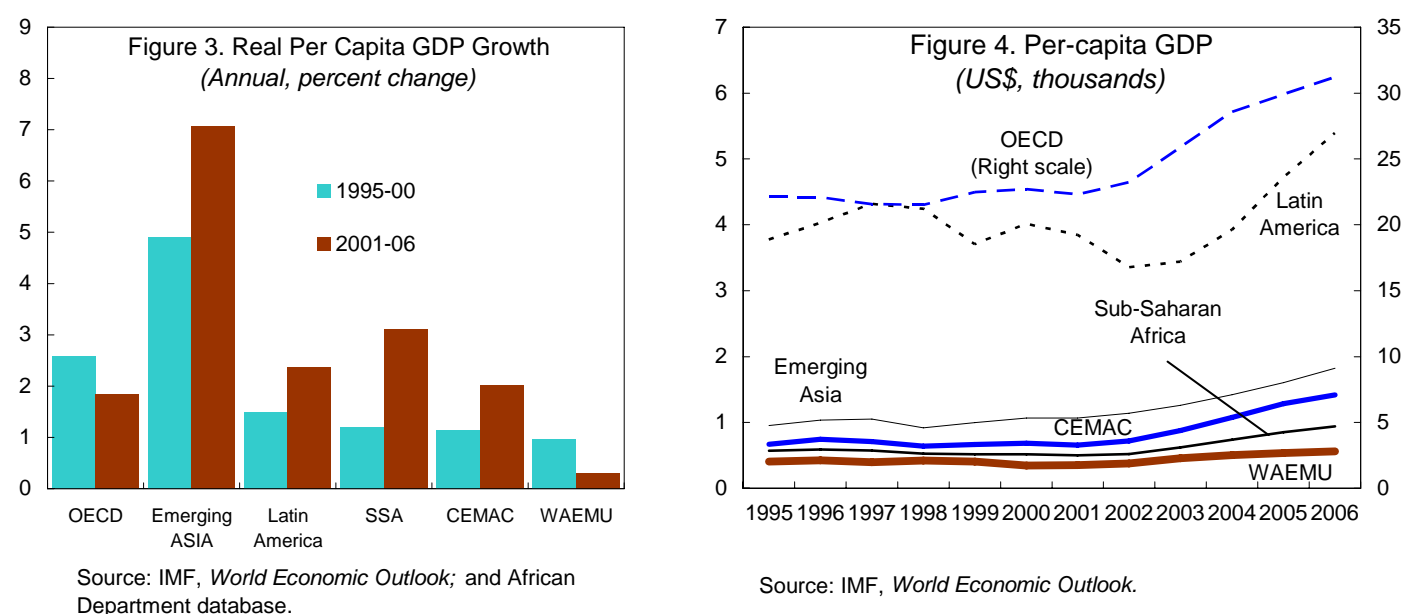
Department database.

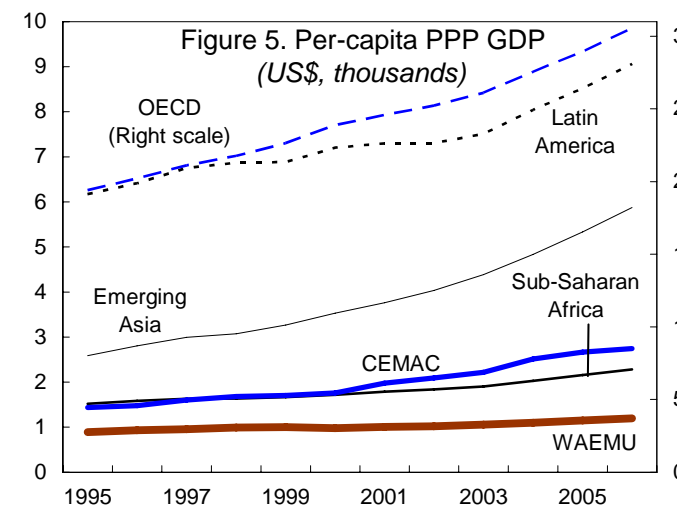

Source: IMF, World Economic Outlook.

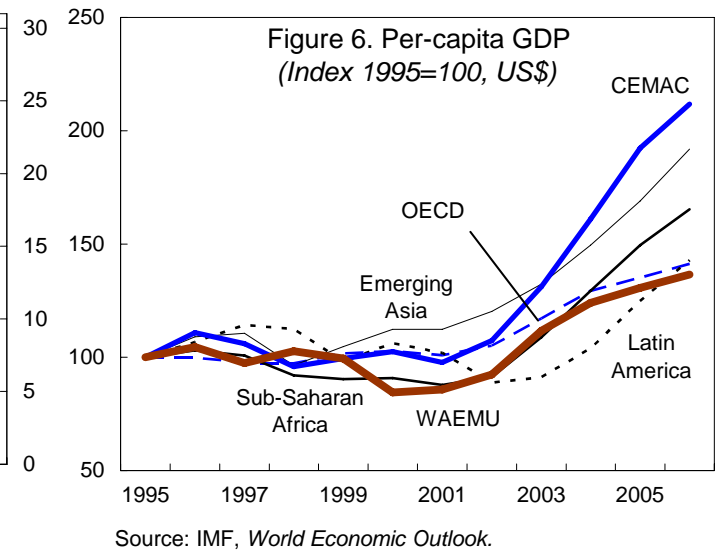

Source: IMF, World Economic Outlook. 
In nominal terms WAEMU and CEMAC output per capita does not compare favorably with peer groups. WAMU and CEMAC rates are below other developing country groups, including Latin America and emerging Asia, both in U.S. dollar and purchasing power parity (ppp) adjusted terms (Figures 4 and 5). Despite the progress CEMAC has been making (Figure 6), its per capita GDP is barely above the SSA average and is below comparator groups both in dollar and ppp terms.

\section{B. Quality of Life}

A key objective of competitiveness is to ensure that the quality of life improves, a concept that goes beyond growth rates and material living standards. We measure quality of life using the UN Human Development Index (HDI), which combines measures of life expectancy, literacy, and income, and a measure of inequality, the Gini coefficient.

In terms of HDI, CEMAC and WAEMU ranks below OECD and other comparator groups like emerging Asia and Latin America, and the CEMAC region performs only marginally above the SSA average (Figure 7). All WAEMU countries rank in the "low human development" part of the HDI, and four WAEMU countries (Guinea-Bissau, Burkina Faso, Mali, and Niger) rank among the five lowest in the index, with virtually no improvement since 2000. CEMAC countries perform only marginally better, with Chad and the Central African Republic (CAR) in the bottom seven of the index and the rest rated as in "middle human development." At about 50 years, life expectancy for both WAEMU and CEMAC ranks much below the averages for emerging Asia and Latin America, both of which are catching up fast with the OECD (Figure 8). Finally, income inequality as measured by the Gini coefficient is higher in CEMAC than WAEMU, about at the SSA average, and above emerging Asia and the OECD (Figure 9).
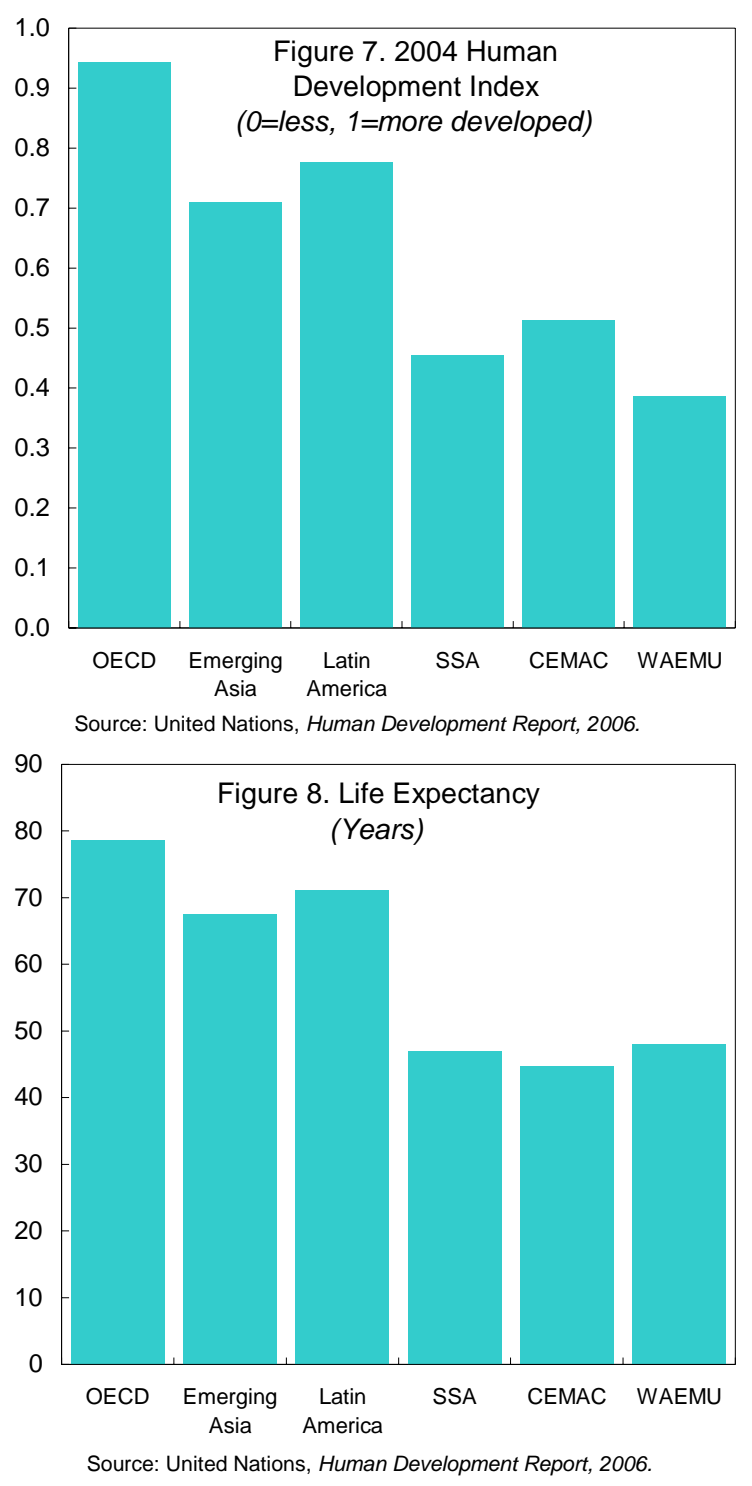

In summary, recent increases in GDP growth rates in both regions have for the most part failed to translate into improvements in the quality of life indicators and sustainable improvements in living standards. 


\section{ENVIRONMENT AND CONDITIONS}

\section{A. Productivity and Labor Markets}

Productivity is a driver of economic growth and important as both determinant and indicator to competitiveness. In general, productivity is a measure relating a quantity or quality of

output to the inputs required to produce it; it often refers to labor productivity, which can be measured by quantity of output per time spent or number of workers employed. ${ }^{9}$

First, we examine the overall productivity of WAEMU and CEMAC using real per capita GDP as a proxy for output per worker. The real per capita GDP growth estimates in Figure 3 suggest that WAEMU productivity is the lowest among all developing country comparator groups including SSA, with the trends indicating a decline since 1995-2000. CEMAC productivity is at about the SSA level and has been improving since 2000.

Next, we construct a productivity index of each region's real per capita GDP against its partner countries, which can give another dimension of productivity. ${ }^{10}$ Looking at this measure, for both WAEMU and CEMAC there is a persistent decline in productivity
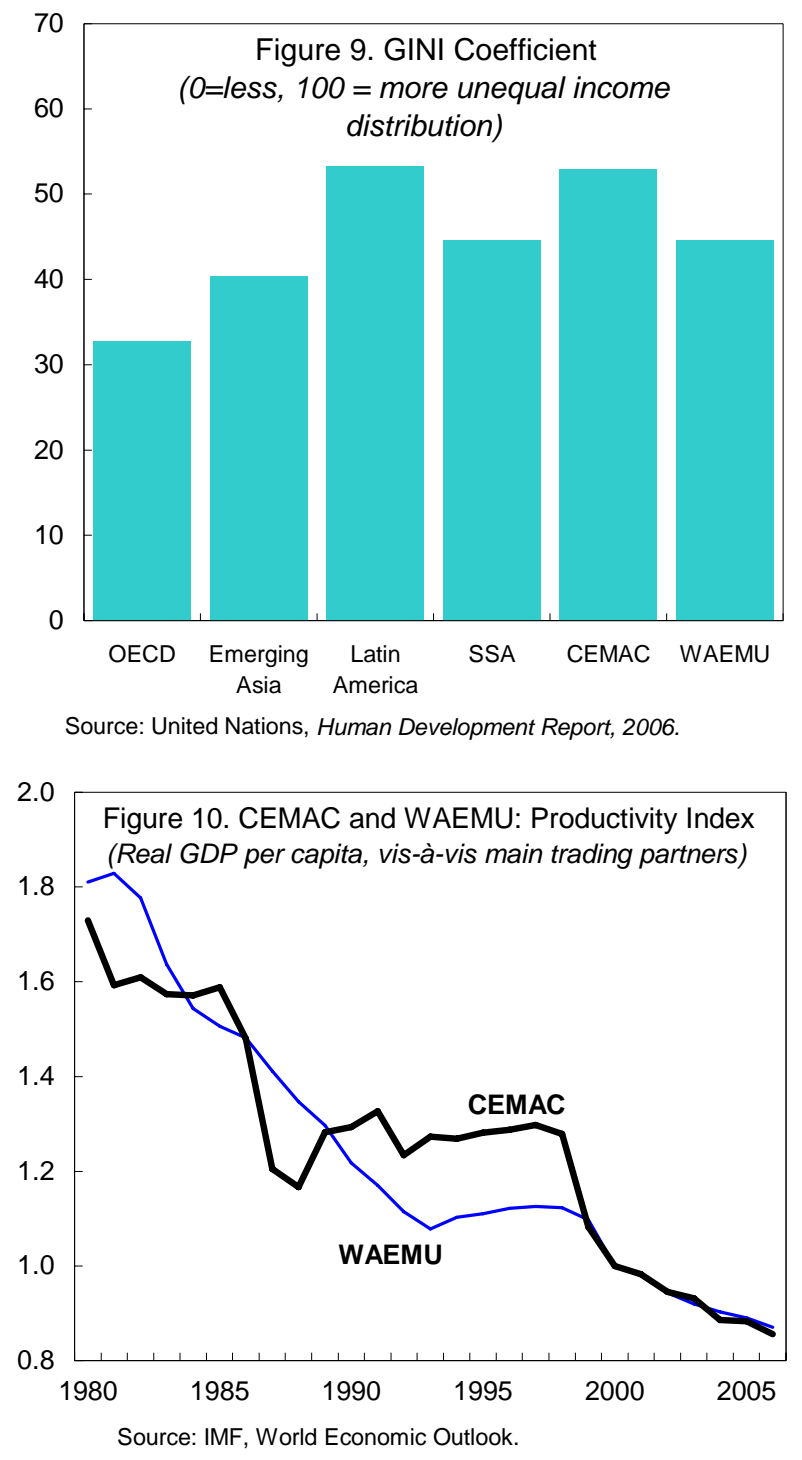
since the late 1990s, with both productivity indices at about the same levels in 2006 (Figure 10).

\footnotetext{
${ }^{9}$ Human and physical capital and resources, technology and innovation, and the macroeconomic and institutional environment determine productivity. We discuss the environment here section and because they are influenced by policy, we discuss human and physical capital, resources, technology, and innovation are influenced by policy in Part IV.

10 This measure is typically used in equilibrium real effective exchange rate analyses. The productivity index is constructed as the ratio of real per capita GDP relative to each region's main trade partners (in logarithmic terms), normalized for each region to 1 in 2000. See Abdih and Tsangarides (2006) for more details.
} 
The cost of inputs in the production process is another determinant of competitiveness. A measure of these costs that also measures international competitiveness is the unit labor cost (ULC), which essentially combines labor cost and productivity. The International Labor Organization's Key Indicators of the Labor Market Program (KILM) gives ULC comparisons mainly for developed economies, because (i) for developing countries information on labor compensation is inadequate, particularly on employers' costs (such as social security contributions), and (ii) in developing countries there is a relatively large share of self-employed persons operating in the informal sector, which complicates the analysis of ULCs. ${ }^{11}$ We therefore focus on measures of labor market conditions, particularly supply.

With no data available on unemployment rates, we examine other demographic and labor market characteristics in WAEMU and CEMAC (Figure 11). For 1990-2004, the average population growth rate in WAEMU was about 2.7 percent, higher than both CEMAC and SSA, almost twice as high as in lower and middle-income (LMI) countries and Latin America, and more than twice as high as the East Asian countries. In a Malthusian view, these rates do not translate into a larger labor force but into higher resource constraints. At about 79 percent in 2004, total labor force participation rates in WAEMU compare favorably to those of SSA (76 percent), LMI countries (71 percent), and Latin American countries (70 percent). While marginally below the SSA rates in 2004,

Figure 11. Demographics and Labor Market
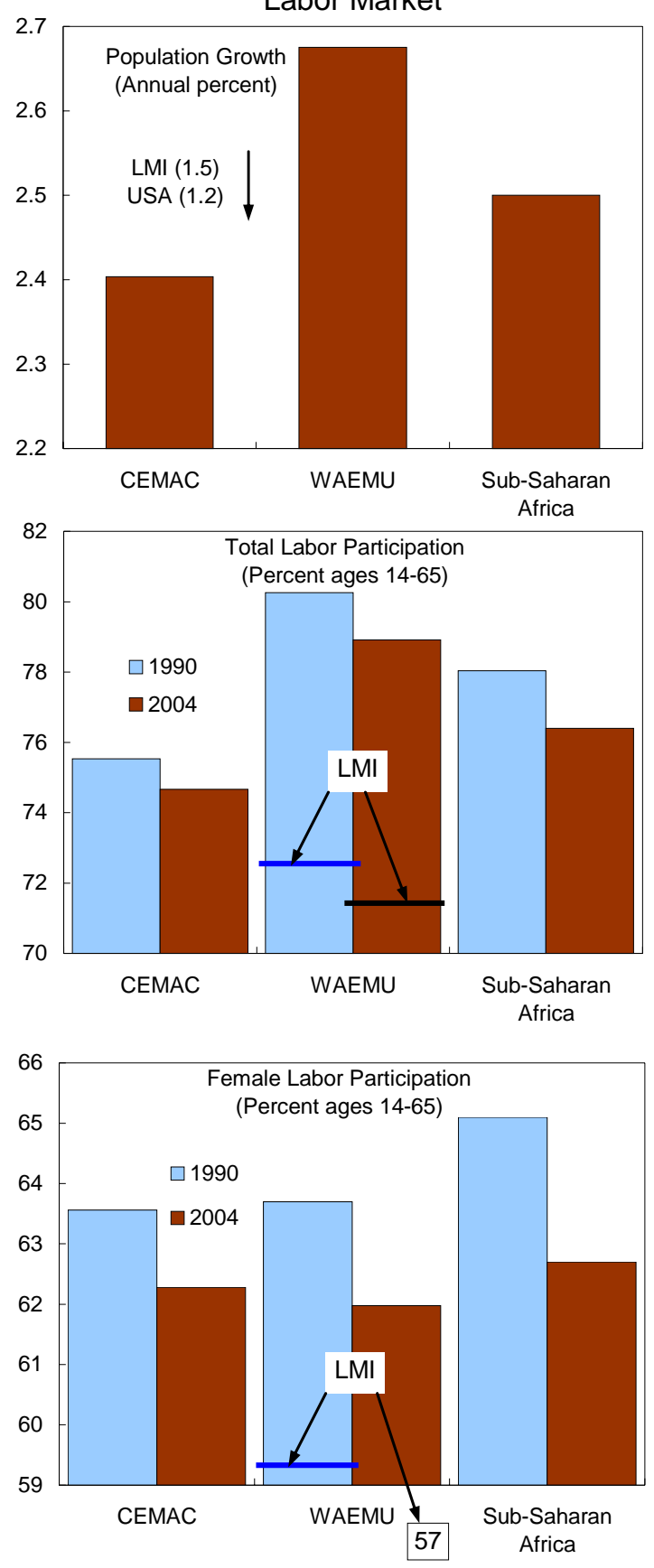

Source: World Bank, World Development Indicators, 2006. female labor force participation in both

\footnotetext{
${ }^{11}$ See KILM’s “Unit labor costs, productivity and international competitiveness” available http://www.ilo.org/public/english/employment/strat/kilm/.
} 
WAEMU and CEMAC compares favorably with other groups, including LMI countries (57 percent) and Latin American countries (55 percent).

In summary, measured productivity compared with trading partners for both WAEMU and CEMAC has been declining. While high population growth rates exert a resource constraint, some labor market conditions, such as labor force participation, appear promising when contrasted with comparator groups.

\section{B. Costs and Prices}

Because they have an immediate incidence on the prices and profitability of exports and importcompeting goods relative to other products, exchange rates are widely used measures of competitiveness. Cost and price indicators measure either the extent to which traded goods and services can compete with those of other countries, or the extent to which production of traded goods and services is attractive relative to the production of nontraded goods and services. To measure these costs we use a variety of exchange rate indicators, including real effective exchange rates based on consumer price indices and labor costs, internal exchange rates, and unified exchange rates compared to partners.

\section{Exchange rates}

\section{Real effective exchange rates}

The 1994 devaluation helped to make the CEMAC and WAEMU countries more competitive. It was followed by a steady appreciation of the REER (Table 1, and Figures $12 \mathrm{a}$ and $12 \mathrm{~b}) .{ }^{12}$ Since then, the CEMAC REER appreciated cumulatively by about 32 percent through December 2000 and by another 21 percent from January 2001 to December 2006; by December 2006 the CEMAC REER was at 86 percent of its predevaluation level. The WAEMU REER appreciated by about 21 percent through December 2000 and by another 11

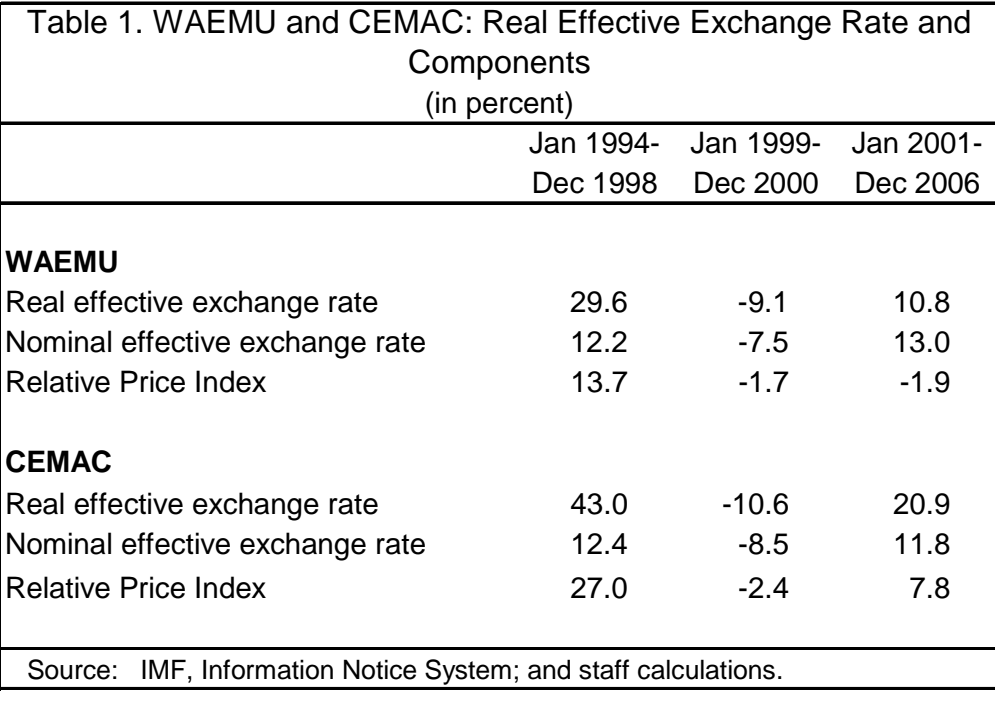
percent from January 2001 to December 2006; by December 2006 the WAEMU REER was at

\footnotetext{
12 The regional aggregate REER for CEMAC and WAEMU were constructed using weighted averages of the individual countries’ REERs. The weights are based on nominal GDP.
} 
77 percent of its predevaluation level. For both the WAEMU and CEMAC the most recent appreciation was essentially due to the strengthening of the Euro to which the CFA franc is pegged. $^{13}$

There are significant variations around the regional averages among member countries of each region (Figures 13a and 13b). Within WAEMU, Benin has experienced the highest appreciation since the 1994 devaluation and Mali the lowest. By December 2006 Mali's REER stood at 66 percent and Benin's at 89 percent of the predevaluation levels. In the CEMAC, there was a much wider variance of REERs partly because of the new oil producers. At end-2006, Equatorial Guinea had the highest appreciation (116 percent of the predevaluation level) and Gabon the lowest (70 percent).

\section{Internal real exchange rate}

The internal real exchange rate (IRER) can be an appropriate measure of competitiveness for small economies where the cost of production is reflected in the price of nontradable goods and the price of imports is determined in the world market. It is measured as the ratio of the prices of nontraded goods $\left(\mathrm{P}_{\mathrm{NT}}\right)$ to those of tradable goods $\left(\mathrm{P}_{\mathrm{T}}\right)$. This in itself presents a difficulty because there is no straightforward definition of what are tradable and what are nontradable goods. For a robustness check of our results, we use two different approaches used in the literature (denoted as $\operatorname{IRER}_{1}$ and $\left.\mathrm{IRER}_{2}\right){ }^{14}$

In the CEMAC fluctuations in the IRER followed those of the CPI-based REER but with wider amplitude; for the WAEMU the IRER was in line with the CPI-based REER (Figures 14a and 14b). In the case of CEMAC, the IRER suggests slightly more erosion of competitiveness than is suggested by the CPI-based REER. Specifically, by end-2006 the total cumulative yearly appreciation of the IRER since 1994 was about 11 percent, bringing it to 91 percent of its predevaluation value, while the CPI-based REERs was 86 percent above its predevaluation value. ${ }^{15}$ For the WAEMU, the IRER measures track the CPI-based REER very closely until about 2003, suggesting that the CPI-based REER captures the costs of production adequately. After 2003 the CPI-based REER seems in a sense to overestimate the erosion of competitiveness, because both the IRER measures are below the REER.

\footnotetext{
${ }^{13}$ For CEMAC, the three main trading partner countries and their weights were France (0.29), United States (0.11), and Germany (0.09). For WAEMU, they were France (0.27), Germany (0.10), and the United States (0.09).

${ }^{14}$ Details on the calculation of the IRER using two alternative methodologies are presented in Appendix A. The same methodology was applied in Central African Economic and Monetary Community: Selected Issues, IMF Country Report No. 05/390.

${ }^{15}$ For both WAEMU and CEMAC total cumulative yearly appreciation of the IRER is calculated as a simple average of the two measures of IRER.
} 

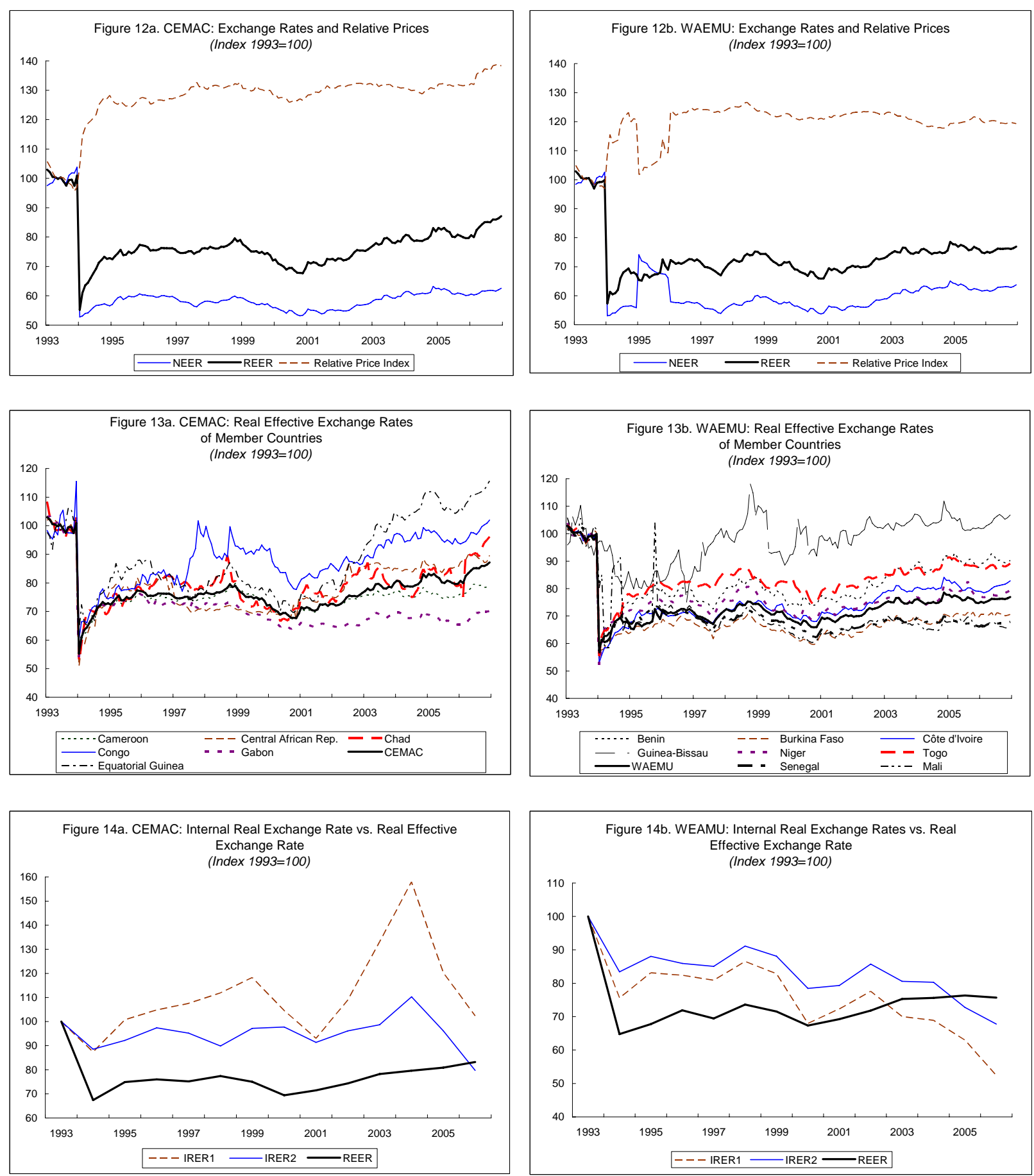


\section{Labor costs and other real exchange rate measures}

Labor cost based REERs have remained below the CPI-based REERs in both CEMAC and WAEMU (Figures 15a and 15b). ${ }^{16}$ CEMAC's labor-cost-based REER depreciated much more than the CPI-based REER after the devaluation and has remained lower at about 62 percent of
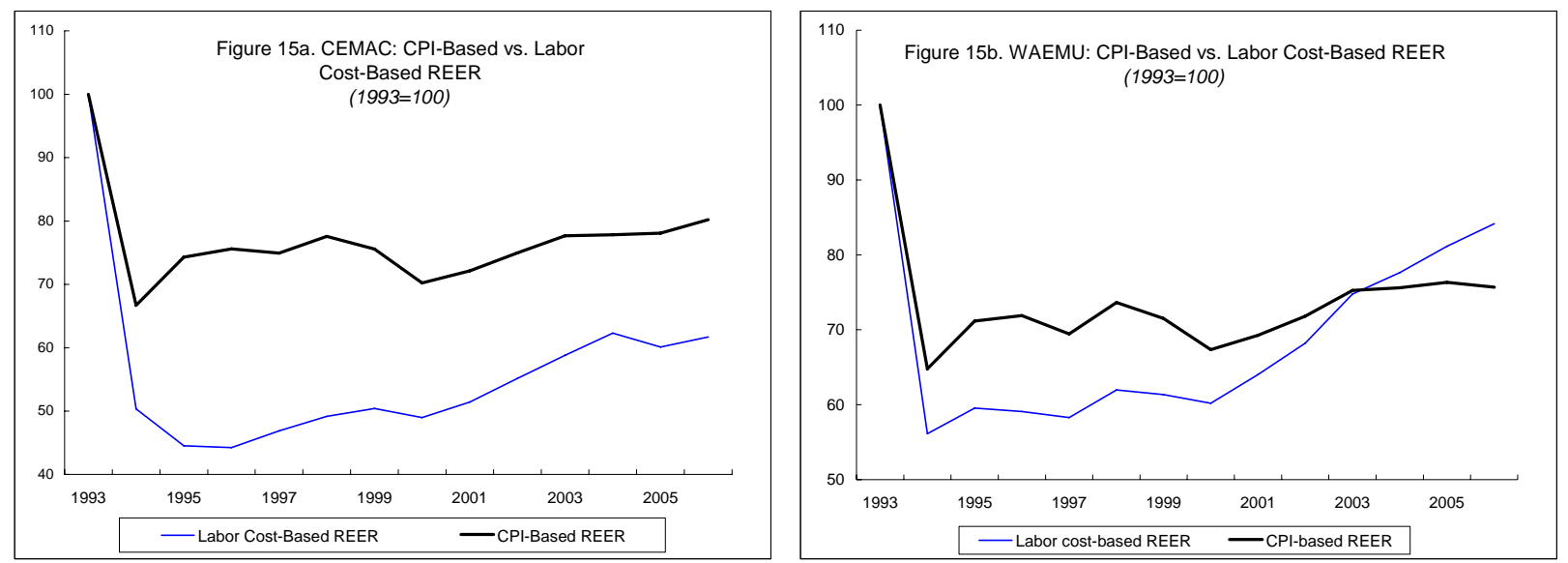

its predevaluation level. The WAEMU labor-cost-based REER followed a similar pattern up to 2003 but since then has been appreciating faster than the CPI-based REER, suggesting that recently labor costs in WAEMU have been rising faster than prices. Overall, with the exception of WAEMU after 2003, labor-cost-based measures suggest that for both regions competitiveness in international markets appears to be more favorable when cost-based rather than CPI-based REERs are used. Particularly for the case of CEMAC, the finding that CPIbased REER appreciated more than the labor cost-based REER could be an indication of Dutch disease. In addition, for both regions, the stronger depreciation of the labor-cost based REER compared to the CPI-based REER suggests that there was a downward adjustment of nominal wages.

The service-sector-deflator-based REERs give a somewhat different picture. It has been lower than the CPI-based REER in the CEMAC (Figure 16a) but above it in the WAEMU region (Figure 16b).

\footnotetext{
${ }^{16}$ Because of data limitations, labor-cost-based REER is proxied by the CPI-based REER multiplied by the real wage index (= nominal wage index/CPI). This proxy is our best approximation because there is little if any reliable data on labor costs for many trading partners.
} 


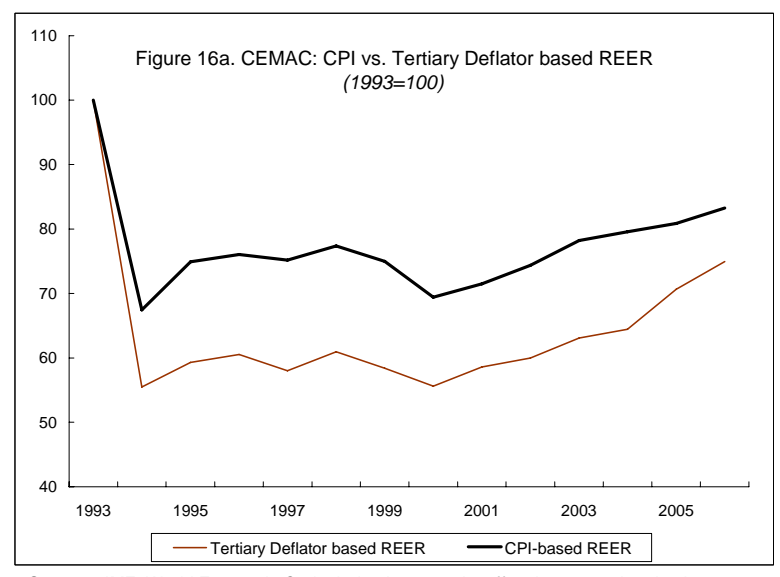

Sources: IMF, World Economic Outlook database; and staff estimates and projections.

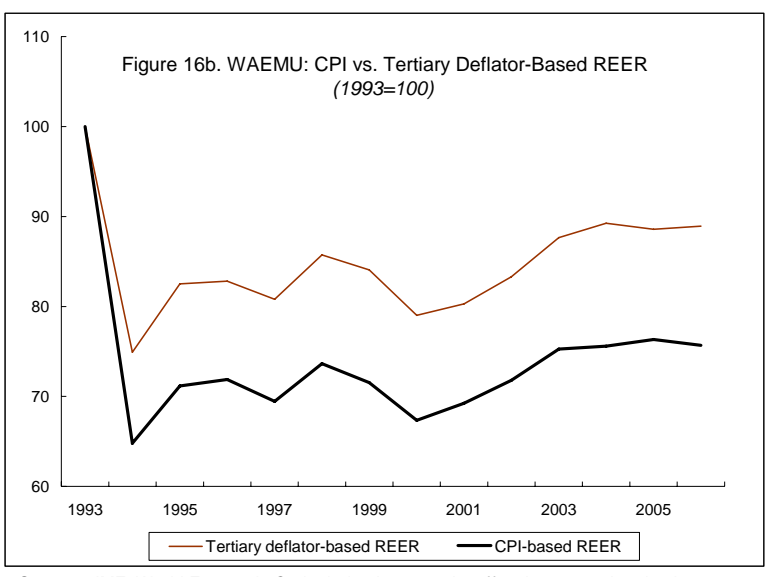

Sources: IMF, World Economic Outlook database; and staff estimates and projections.

\section{Unified regional exchange rates}

As a robustness measure of the (CPI-based) REER, we treat each region as an economic unity and measure the international price competitiveness of the common currency union. As for the Euro area, we construct a measure of the unified regional exchange rate (URER) in both nominal and real terms (URNEER and URREER). These aggregated indicators are constructed so that individual country domestic prices are weighted by the trade between the monetary union as a whole and the rest of the world, thus excluding (by construction) intra-union trade, which in some cases might bias the regional competitiveness indicator. ${ }^{17}$ We also decompose URERs between partners to observe any specific patterns.

Average URNEER for CEMAC now stands at about 60 percent of its predevaluation level at end-2006 (Figure 17a). It reached its minimum in 2000, when the URNEER was at about 50 percent of its 1993 level. Including the effect of relative prices, the CEMAC URREER appreciated about 28 percent from 1994 to 2006 and is now at about 83 percent of its predevaluation level (Figure
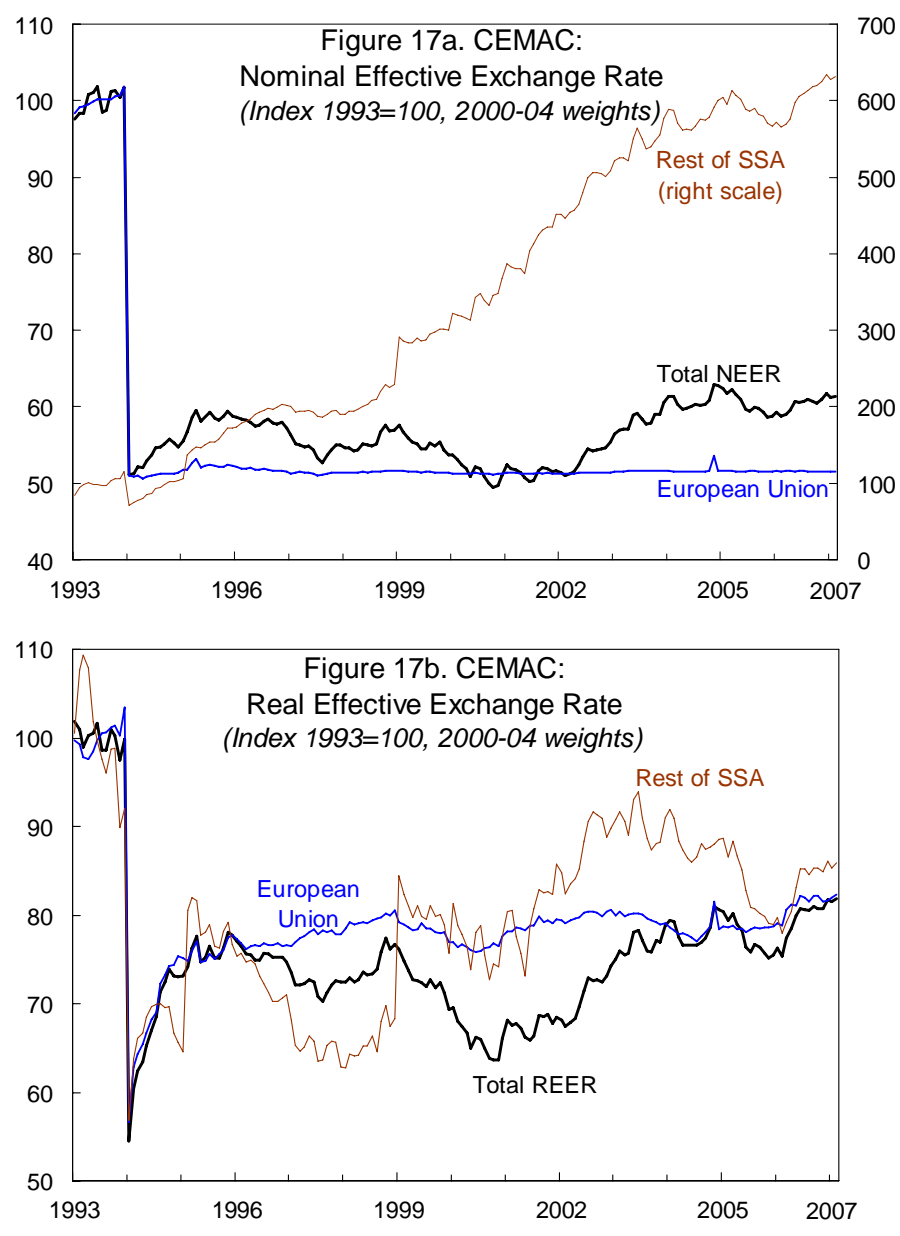

\footnotetext{
${ }^{17}$ Details on the calculation of the UREER are presented in Appendix B. For more details see Ramirez and Tsangarides (2007).
} 
17b). Immediately after the 1994 devaluation, the CEMAC URREER appreciated to about where it was at the end of 2006, but it depreciated from December 1995 to October 2000 before turning around for four years of significant appreciation (21 percent from its low in 2000 to December 2004); there has since been no clear trend. Due to the peg to the Euro, the URREER relative to the European Union is less volatile than total URREER. The end-2006 levels of the CEMAC URNEER and URREER are both consistent with the NEER and REER.

The WAEMU URNEER has appreciated by about 30 percent since 1994 and is currently at 80 percent of its predevaluation level (Figure 18a). By 2007, its URREER was at about 72 percent of the predevaluation level (Figure 18b). There was significant appreciation in the two years after devaluation, but the index has been fluctuating since around a relatively stable mean. Unlike the URRER compared to the EU, the WAEMU URREER compared to trade partners in SSA is more volatile, and there were episodes of extreme depreciation in February 1995 and in January 1999. Comparing to the conclusions based on the WAEMU NEER and REER, at the end of 2006, the URNEER was about 20 percent higher than the NEER, and the URREER was about 5 percent lower than the REER.

\section{Equilibrium real exchange rates}

Assessing competitiveness and necessary exchange rate or other appropriate policy action also requires a quantitative analysis of the actual and equilibrium exchange rate (EREER). While this paper does not explicitly analyze the movements of the REERs of the two monetary unions of the CFA franc zone vis-à-vis their long-run equilibrium values, we can draw conclusions based on the recent work by Abdih and Tsangarides (2006). Using the fundamentals equilibrium exchange rate (FEER) approach based on the Edwards (1989) model and the Johansen (1995) cointegration methodology, the authors identify certain fundamentals that account for most of the fluctuation of the real effective exchange rates: increases in the terms of trade, government
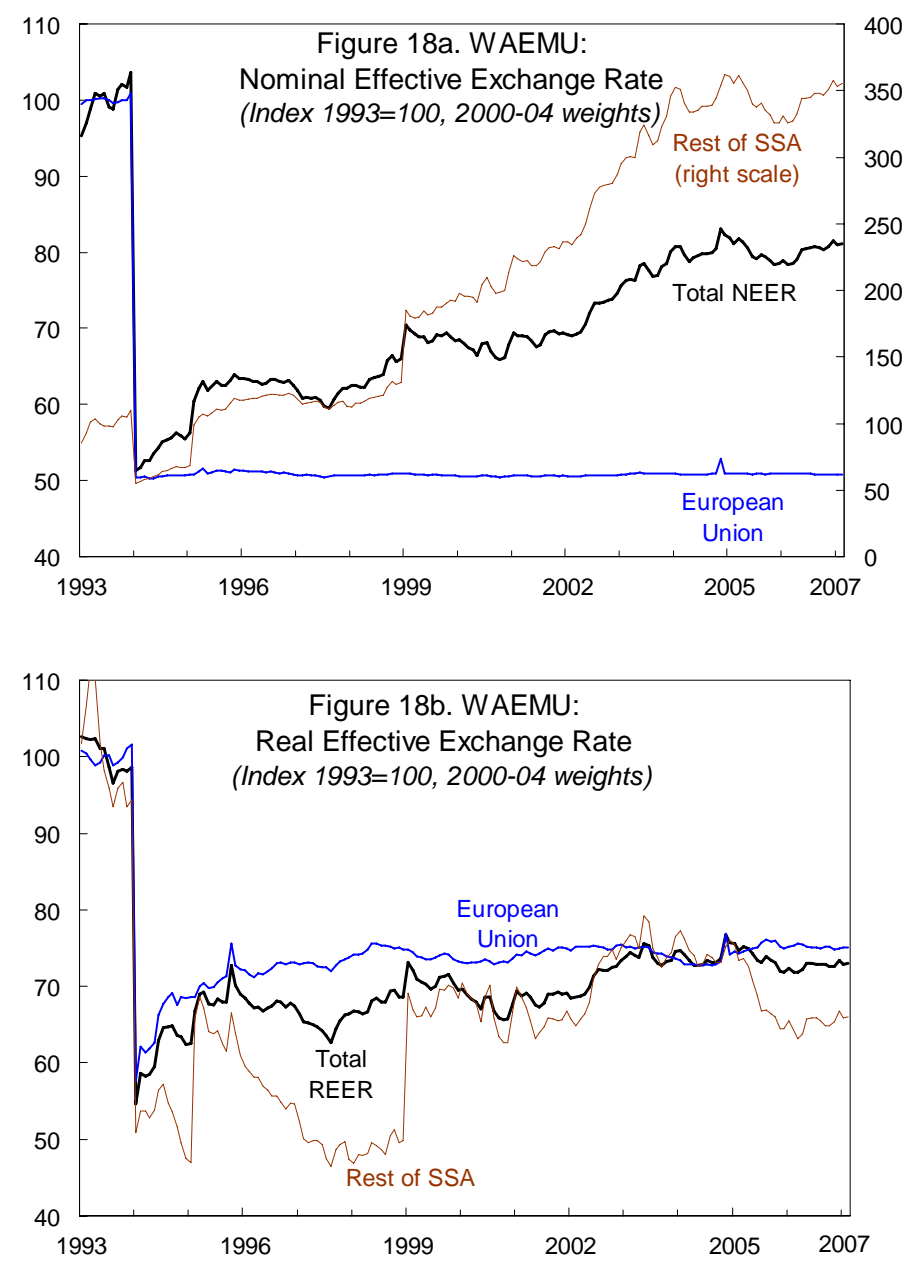
consumption, and productivity improvements tend to cause the exchange rate to appreciate, while increases in investment and openness lead to a depreciation. Based on these fundamentals, Abdih and Tsangarides estimate that while both the WAEMU and CEMAC real exchange rates 
were slightly more appreciated than their estimated long-run equilibrium levels at end-2005, the estimated misalignments were not statistically significant. This sugegsts that at end-2005 both the CEMAC and WAEMU real effective exchange rates were broadly in line with their long-run equilibrium values. ${ }^{18}$

\section{Labor costs and wages}

Given the lack of reliable data on total production costs in the two regions, the analysis focuses on labor costs. Since there is no first-hand data on the wage rate of the countries as a whole (including the private sector), we use an index of wage rates of civil servants as its proxy. ${ }^{19} \mathrm{We}$ then construct a nominal wage index for each country in the zone using data on total wage and salary expenditures of the government, together with the number of civil servants (for WAEMU) or the population (for CEMAC, where data on the number of civil servants is not available). We proxy real wages by the ratio of the nominal wage index to CPI.

Nominal wages tend to have grown slower than other domestic prices in most countries in both zones. By the end of 2006, CEMAC countries showed a similar decline in the real wage index except Equatorial Guinea (where government expenditures increased sharply with oil revenues) and Gabon (Figure 19a). In the WAEMU real wages in 2006 were lower than in 1993 in Burkina Faso, Côte d'Ivoire, Niger, and Togo but through 2003 had risen in Benin, Mali, and Senegal (Figure 19b). The decline in real wages was most noticeable at the time of the devaluation, because exchange rate pass-through to wages is weaker than pass-through to other prices. $^{20}$

\footnotetext{
${ }^{18}$ Further, in the context of the IMF's 2007 Article IV discussions, the analysis of Abdih and Tsangarides (2006) was extended for both the WAEMU and CEMAC EREERs up to 2006 (see SM/07/119 and SM/07/212). This work concludes that in 2006 also the levels of the real effective exchange rates were in line with the estimated equilibrium real effective exchange rate paths, without any statistically significant misalignments.

${ }^{19}$ The analysis focuses on the wage index (and consequently the rate of change in wages), not the wage level. This allows us to explore the evolution of wage rates over time without needing information on the wage level in the private sector (or the ratio of public sector to private sector wages). An index based on civil servant wages should capture well the movement of wage rates of the economy as a whole as long as public and private sector wages tend to move together (which is likely at least over the long term).

${ }^{20}$ Unit labor costs (that is, labor costs adjusted for labor productivity) would have been computed had reliable data been available. Since it was not, we resorted to per capita GDP as a proxy for labor productivity.
} 

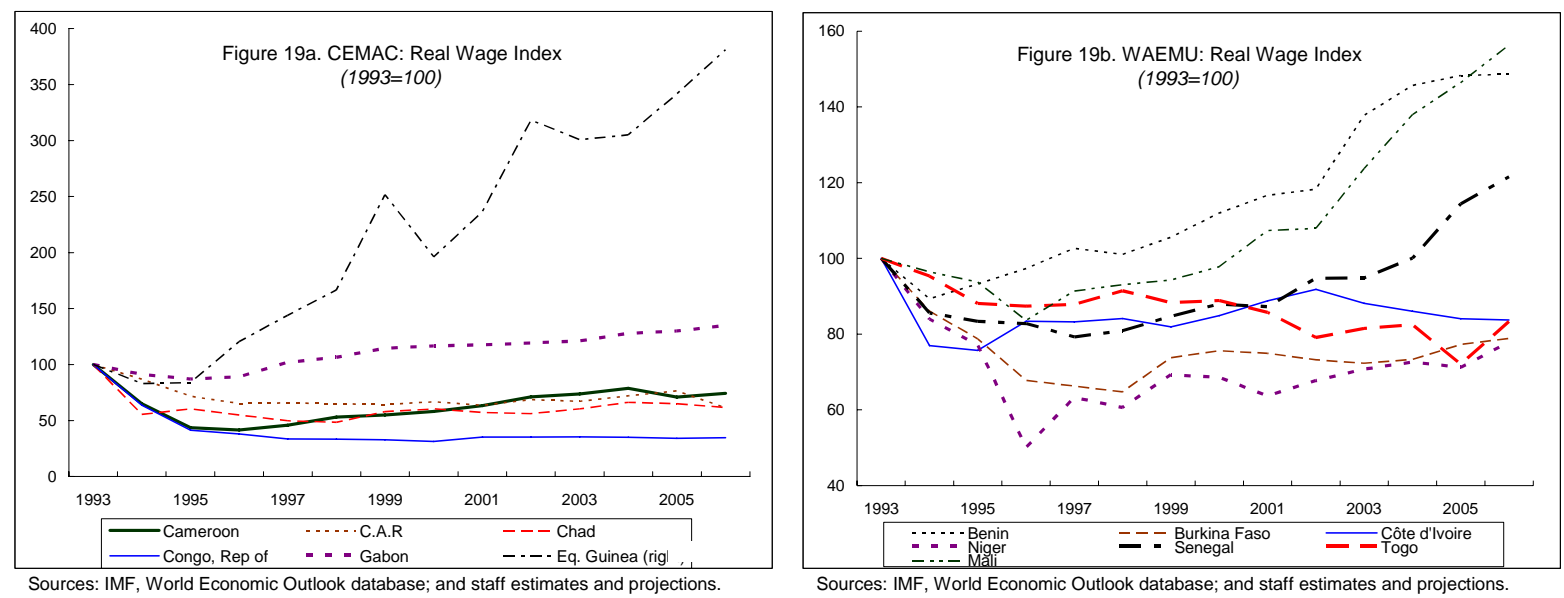

In summary, the various real exchange rate measures point to an appreciation of the CFA franc in both WAEMU and CEMAC, suggesting a loss of competitiveness. However, the constructed nominal wage indices show that nominal wages have grown slower than other domestic prices in the majority of the countries in both regions.

\section{Macroeconomic Performance}

Macroeconomic performance indicators measure the evolution of export flows and market shares, as well as foreign direct investment (FDI) flows. Strong export growth (if not associated with equally strong import growth), expansion in export market shares, and increasing export diversification suggest improved competitiveness. Such trends are also associated with increasing profitability of exports, measured as falling unit costs or increasing value-added. FDI flows also reflect the attractiveness of a country's investment climate and tend to be correlated with increases in exports.

\section{Export patterns and market shares}

Since 2001, CEMAC shares of the export market to the world have been increasing, to Africa declining, and to the EU roughly constant (Figure 20a). ${ }^{21}$ Intra-CEMAC trade has been virtually flat at about 1 percent since 2000. Over the same period, WAEMU market shares to the world appear to be increasing, and for Africa and the EU decreasing (Figure 20b), but intra-WAEMU exports have been expanding and are much higher than intra-CEMAC exports.

\footnotetext{
${ }^{21}$ Shares defined as the ratio of a region's total exports to the total imports of selected groups.
} 


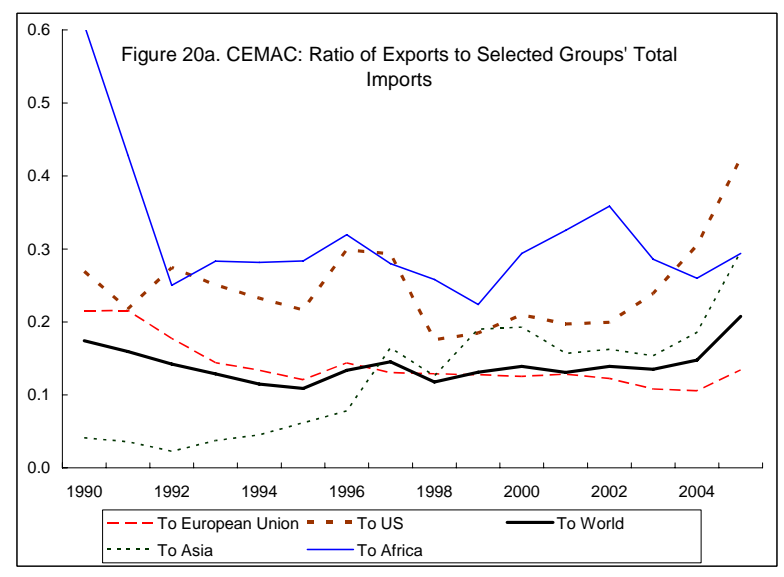

Sources: IMF, Direction of Trade Statistics; and staff estimates and projections.

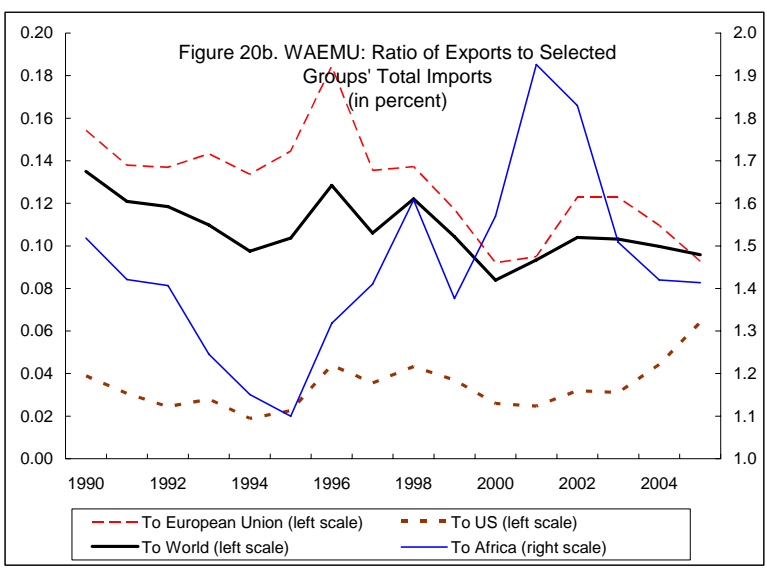

Sources: IMF, Direction of Trade Statistics; and staff estimates and projections.

The evolution of the exports to GDP ratio and the volume growth rates for CEMAC are shown in Figure 21a and for WAEMU in Figure 21b. For WAEMU, exports-to-GDP have been increasing and since 2000 volumes (although volatile) have been growing by an average of 2 percent. For the CEMAC region, export performance has been dominated by the oil sector, as is evident by the increase of both the share and volume of oil exports. Since 1997 there has been a decline of non-oil exports to GDP, though they began to pick up in 2005. In comparison to

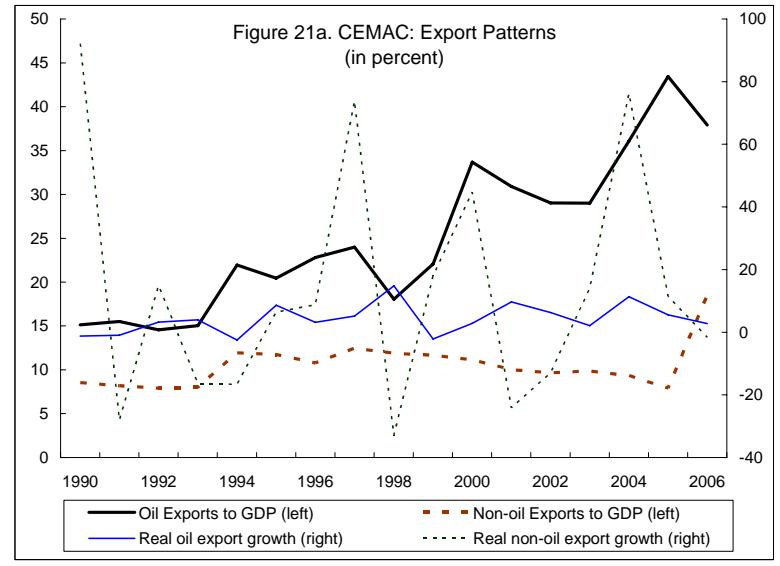

Sources: IMF, World Economic Outlook database; and staff estimates and projections.

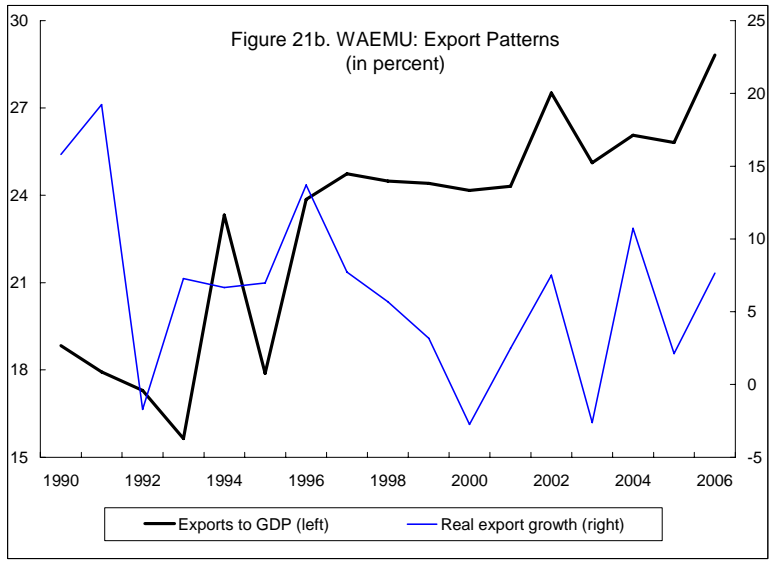

Sources: IMF, World Economic Outlook database; and staff estimates and projections.

export shares of other groups, CEMAC average exports-to-GDP in 2001-06 are higher than in Latin America, SSA, and OECD, and almost at the level of emerging Asia. At about 31 percent, WEAMU's average export shares are below SSA generally but compare favorably to the other comparator groups (Figure 22).

\section{FDI and diversification}

FDI flows to developing countries are good sources of non-debt-creating capital, offering access to advanced technology and global marketing networks. FDI flows (and stocks) to developing countries vary because countries differ in their ability to attract FDI, depending on their market size, labor costs, and human capital and technology. Figure 23 shows that emerging Asia has 
attracted the majority of FDI-US\$1.4 billion in 2005, almost twice as much as the next developing country group, Latin America. While FDI in both WAEMU and CEMAC is low in dollar terms, it has been significant as a share of GDP (Figure 24). FDI in CEMAC has been steadily increasing, surpassing other SSA countries since 2001, primarily due to oil-related investments; it amounted to about 40 percent of the region's GDP in 2005. In WAEMU FDI has been flat at about 15 percent of regional GDP since about 2000. In SSA as a whole FDI has been declining since 2003; in 2005 it was 30 percent of GDP. As a comparison, FDI flows represent about 2.5 percent of GDP in lowermiddle-income countries, 3.0 percent in Latin America, and 2.4 percent in East Asia and Pacific; 3.2 percent in SSA as a whole; 7.1 percent in CEMAC; and just 0.9 percent in the WAEMU. Loss of competitiveness may be due to patterns of specialization. We examine this possibility by comparing the evolution of the growth of market share of WAEMU exports in 200005 with the evolution of world export prices. We perform the analysis only for the WAEMU because in the CEMAC all export developments are dominated by oil. The bottom two quadrants of Figure 25 identify commodities whose prices increased less than average export prices. The two right quadrants identify areas where WAEMU export growth was higher than the world average. The size of the bubble reflects the importance of the commodity
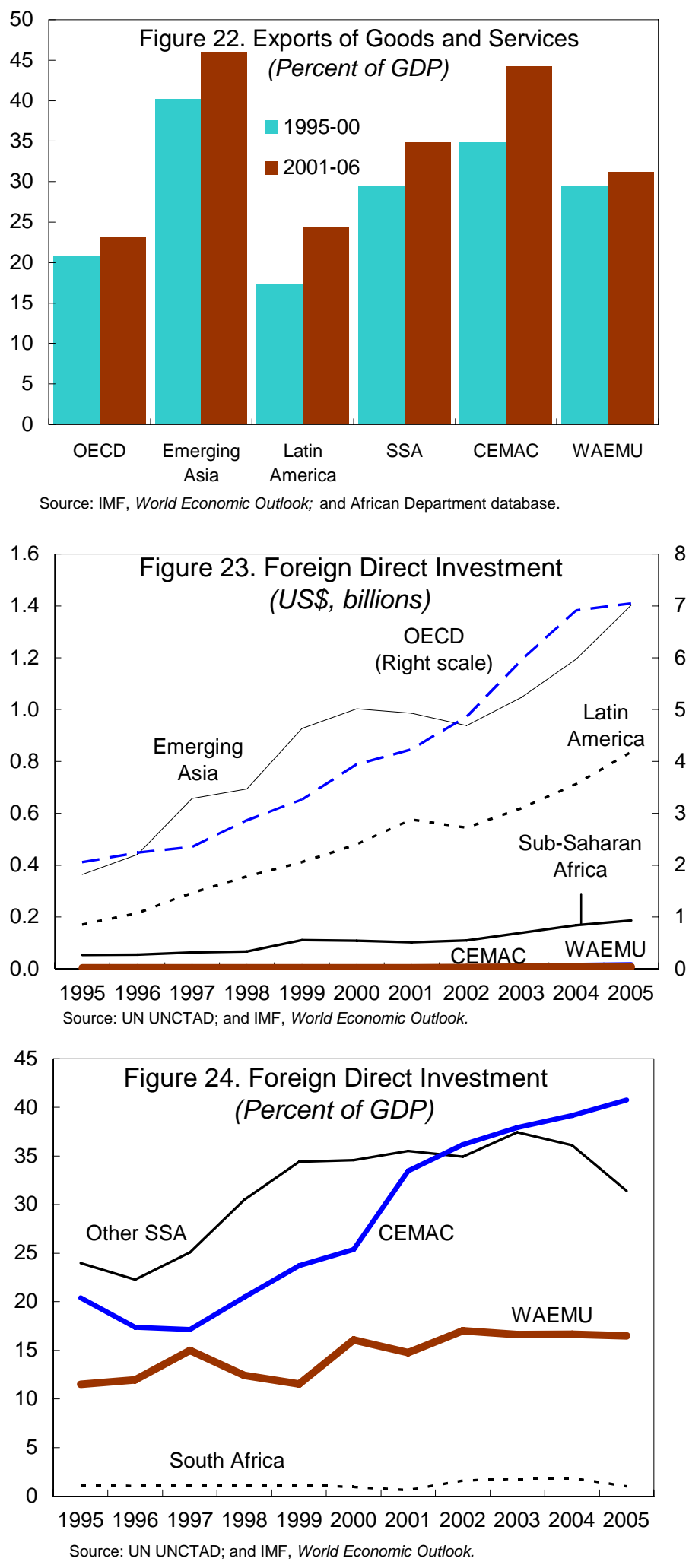
inWAEMU trade. The figure makes it clear that, excluding fuels, cocoa, and iron, for 200005 the average growth in exports in US dollars of the products that WAEMU countries export was below the overall average for total world exports. In addition, for all these products, average price increases were lower than the world export average. In contrast, in the markets for cocoa and iron export price increases have been higher than average, and higher than average export growth. The weight that cocoa has in the WAEMU trade is what is driving explains WAEMU export performance; the other sectors have not been doing so well.

In summary, export volumes show improvement in both regions, dominated in the CEMAC by the oil sector. Export growth for WAEMU was much slower than for CEMAC but showed some diversification. Export market shares have been increasing in some markets and worsening in others. FDI has been increasing in CEMAC and compares favorably with the rest of the SSA, but has stagnated for WAEMU.

\section{Policy}

\section{A. Business Environment}

\section{Profitability}

The profitability of exports in CEMAC has been driven by the oil sector, where profitability is driven by fluctuations in oil prices fluctuation, which have been rising in recent years. Figure 26a shows that the impact of the appreciating REER was somewhat contained over the past two years, as CEMAC exports increased, terms of trade improved due to oil price increases, and export profitability generally was enhanced. Figure 26b shows an overall deterioration of the terms of trade for WAEMU since about 1995, coupled with an appreciation of the REER, which suggests challenges export competitiveness and profitability, while, at the same time, there was an overall improvement of the export index. 


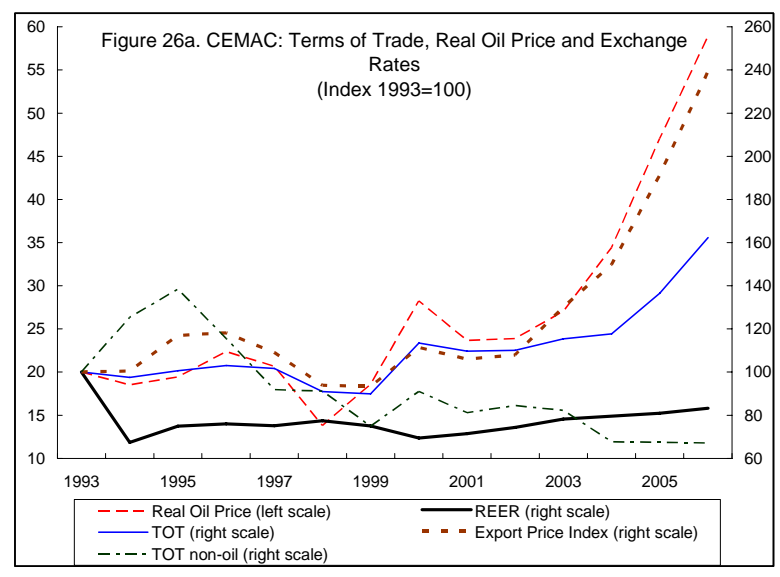

Sources: IMF, World Economic Outlook database; and staff estimates and projections.

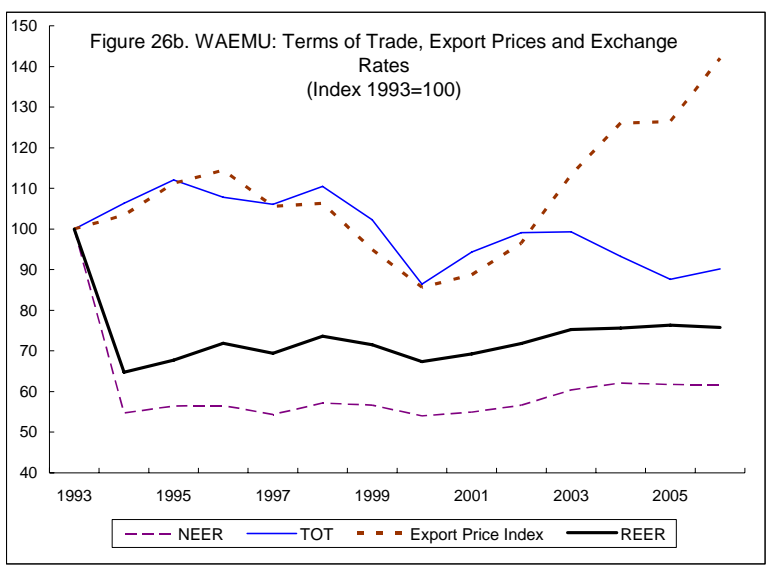

Sources: IMF, World Economic Outlook database; and staff estimates and projections.

While overall export and oil export profitability have been improving, there is evidence of an erosion of the profitability of non-oil exports in CEMAC. We therefore construct two direct measures of profitability, the export price index-to-tertiary GDP deflator and the export price index-to-wages deflator. For CEMAC, we also construct oil and non-oil indices to investigate the profitability of each sector separately. Both indices (Figures 27a and 28) show clearly that

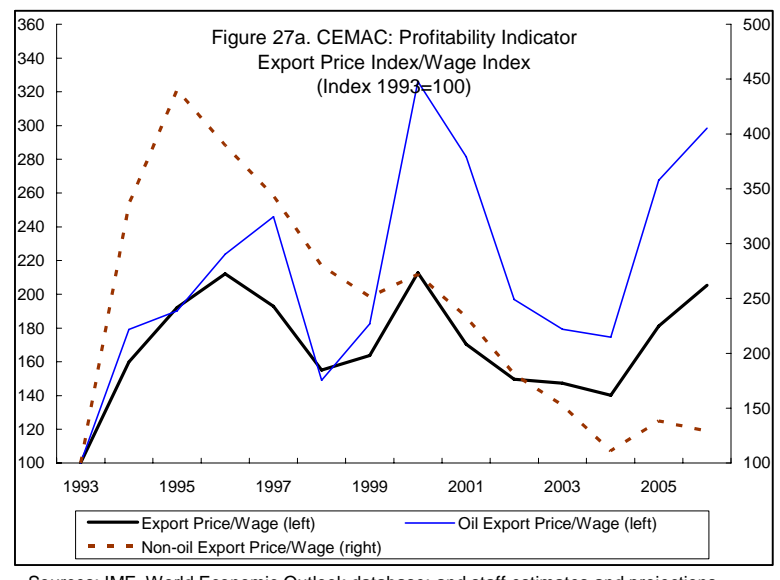

Sources: IMF, World Economic Outlook database; and staff estimates and projections

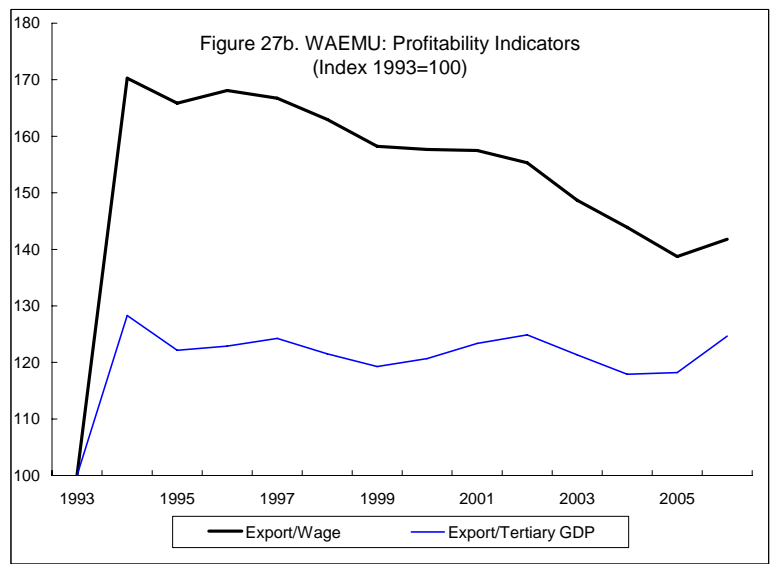

Sources: IMF, World Economic Outlook database; and staff estimates and projections.

while the profitability of exports generally has been increasing in the last two years, this is driven by the oil sector; non-oil-sector profitability has been steadily declining since 2000. For WAEMU (Figure 27b), the indices show (on average) a net decline in profitability since 2002 .

\section{Survey-based indicators of the business environment}

Survey-based indicators of the business climate and governance are useful measures of the indirect costs of production, such as

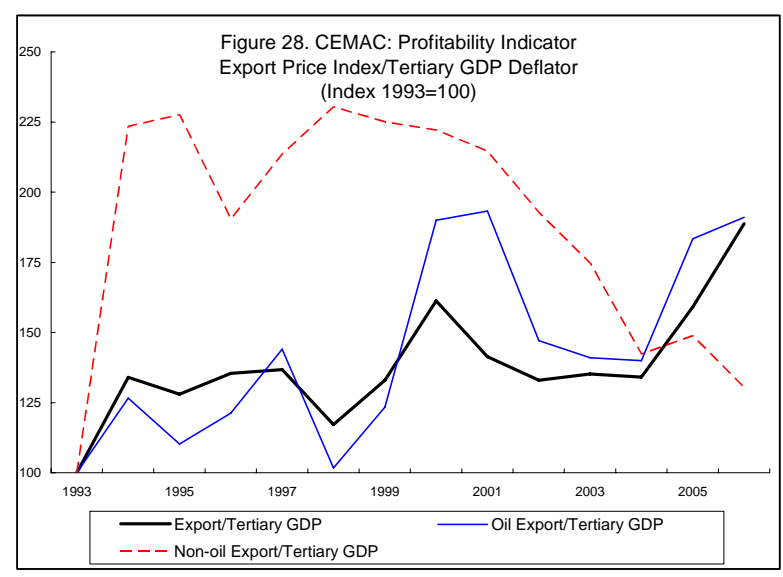

Sources: IMF, World Economic Outlook database; and staff estimates and projections. 
inefficient or unpredictable regulation and institutions (e.g., corruption, red tape, and the inability to enforce contracts). Among the sources with the most relevant information is the World Bank's Doing Business Database, which covers 186 countries, including all WAEMU and CEMAC countries. These indicators are a useful source of micro information to compare different measures of structural advantage or disadvantage for a specific country with those for the whole group.

CEMAC and WAEMU countries rank among the lowest in aggregated ease of doing business (Figure 29). Results of the Doing Business surveys for all these countries show severe structural impediments to developing a competitive private sector (Tables 2a and 2b).

Table 2a. CEMAC: Doing Business Indicators, 2006

\begin{tabular}{|c|c|c|c|c|c|c|c|c|}
\hline & \multicolumn{7}{|c|}{ CEMAC } & $\begin{array}{c}\begin{array}{c}\text { Saharan } \\
\text { Africa }\end{array} \\
\text { Average }^{1}\end{array}$ \\
\hline \multicolumn{9}{|l|}{ Starting a Business } \\
\hline Time (days) & 37 & 14 & 75 & 71 & 136 & 60 & 66 & 62 \\
\hline Cost (\% of income per capita) & 152.2 & 209.3 & 226.1 & 214.8 & 100.7 & 162.8 & 177.7 & 162.9 \\
\hline Min. capital (\% of income per capita) & 187.3 & 554.6 & 414.1 & 192.4 & 13.1 & 36.1 & 232.9 & 209.9 \\
\hline Procedures (number) & 15 & 21 & 16 & 15 & 19 & 13 & 17 & 18 \\
\hline Time (days) & 444 & 245 & 199 & 175 & 156 & 268 & 248 & 236 \\
\hline Cost (\% of income per capita) & 1165.6 & 301.0 & 1139.1 & 1243.0 & 364.9 & 45.3 & 709.8 & 1047.8 \\
\hline \multicolumn{9}{|l|}{ Employing Workers } \\
\hline Difficulty of Hiring Index & 28 & 89 & 39 & 78 & 67 & 17 & 53 & 44 \\
\hline Rigidity of Hours Index & 60 & 80 & 60 & 60 & 60 & 80 & 67 & 52 \\
\hline \multicolumn{9}{|l|}{ Registering Property } \\
\hline Procedures (number) & 5 & 3 & 6 & 7 & 6 & 8 & 6 & 7 \\
\hline Time (days) & 93 & 69 & 44 & 137 & 23 & 60 & 71 & 110 \\
\hline Cost (\% of property value) & 18.7 & 11.7 & 21.2 & 27.2 & 6.2 & 10.5 & 15.9 & 11.6 \\
\hline \multicolumn{9}{|l|}{ Getting Credit } \\
\hline Legal Rights Index & 3 & 3 & 4 & 3 & 2 & 4 & 3 & 4 \\
\hline Credit Information Index & 2 & 2 & 1 & 2 & 2 & 2 & 2 & 1 \\
\hline Public registry coverage (\% adults) & 3.4 & 1.1 & 0.2 & 1.4 & 2.4 & 2.6 & 1.9 & 1.5 \\
\hline \multicolumn{9}{|l|}{ Protecting Investors } \\
\hline Disclosure Index & 8 & 4 & 3 & 4 & 6 & 5 & 5 & 4 \\
\hline Director Liability Index & 2 & 6 & 4 & 5 & 4 & 4 & 4 & 4 \\
\hline Shareholder Suits Index & 6 & 7 & 7 & 6 & 5 & 5 & 6 & 5 \\
\hline \multicolumn{9}{|l|}{ Paying Taxes } \\
\hline \multicolumn{9}{|l|}{ Trading Across Borders } \\
\hline Documents for export (number) & 10 & 9 & 7 & 12 & 6 & 4 & 8 & 8 \\
\hline Time for export (days) & 38 & 63 & 87 & 50 & 26 & 19 & 47 & 40 \\
\hline Cost to export (US\$ per container) & 524 & 1502 & 1860 & 1732 & 1203 & 4000 & 1804 & 1561 \\
\hline Documents for import (number) & 14 & 19 & 14 & 15 & 6 & 10 & 13 & 12 \\
\hline Time for import (days) & 51 & 60 & 111 & 62 & 50 & 26 & 60 & 52 \\
\hline Cost to import (US $\$$ per container) & 1360 & 1572 & 2400 & 2201 & 1203 & 4031 & 2128 & 1947 \\
\hline \multicolumn{9}{|l|}{ Enforcing Contracts } \\
\hline Procedures (number) & 58 & 45 & 52 & 47 & 38 & 32 & 45 & 38 \\
\hline Time (days) & 800 & 660 & 743 & 560 & 553 & 880 & 699 & 581 \\
\hline Cost (\% of debt) & 36.4 & 43.7 & 54.9 & 45.6 & 14.5 & 9.8 & 34.2 & 42.2 \\
\hline \multicolumn{9}{|l|}{ Closing a Business } \\
\hline Time (years) & 3.2 & 4.8 & 10.0 & 3.0 & No practice & 5.0 & 5.2 & 3.5 \\
\hline Cost (\% of estate) & 14.5 & 76.0 & 63.0 & 24.0 & No practice & 14.5 & 38.4 & 20.2 \\
\hline Recovery rate (cents on the dollar) & 24.1 & 0.0 & 0.0 & 19.4 & 0.0 & 13.9 & 9.6 & 17.7 \\
\hline
\end{tabular}

Source: World Bank, Doing Business, 2006

${ }^{1}$ Simple average. 
Table 2b. WAEMU: Doing Business Indicators, 2006

\begin{tabular}{|c|c|c|c|c|c|c|c|c|c|c|}
\hline \multirow{3}{*}{ Starting a Business } & \multicolumn{9}{|c|}{ WAEMU } & \multirow{2}{*}{$\begin{array}{l}\text { Sub-Saharan } \\
\text { Africa } \\
\text { Average }^{1}\end{array}$} \\
\hline & Benin & Burkina Faso & $\begin{array}{c}\text { Côte } \\
\text { d'Ivoire }\end{array}$ & $\begin{array}{l}\text { Guinea- } \\
\text { Bissau }\end{array}$ & Mali & Niger & Senegal & Togo & Average $^{1}$ & \\
\hline & & & & & & & & & & \\
\hline Procedures (number) & 7 & 8 & 11 & 17 & 13 & 11 & 10 & 13 & 11 & 11 \\
\hline Time (days) & 31 & 34 & 45 & 233 & 42 & 24 & 58 & 53 & 65 & 62 \\
\hline Cost (\% of income per capita) & 173.3 & 120.8 & 134.1 & 261.2 & 201.9 & 416.8 & 112.6 & 252.7 & 209.2 & 162.9 \\
\hline $\begin{array}{l}\text { Min. capital (\% of income per capita) } \\
\text { Dealing with Licenses }\end{array}$ & 379.1 & 481.4 & 226.7 & 1028.9 & 519.8 & 778.1 & 269.6 & 539.7 & 527.9 & 209.9 \\
\hline Procedures (number) & 16 & 32 & 22 & 11 & 15 & 19 & 15 & 14 & 18 & 18 \\
\hline Time (days) & 333 & 226 & 569 & 161 & 209 & 148 & 185 & 273 & 263 & 236 \\
\hline $\begin{array}{l}\text { Cost (\% of income per capita) } \\
\text { Employing Workers }\end{array}$ & 338.9 & 1247.5 & 196.3 & 2664.9 & 1813.2 & 2986.7 & 151.6 & 1435.6 & 1354.3 & 1047.8 \\
\hline Difficulty of Hiring Index & 39 & 83 & 44 & 100 & 44 & 100 & 72 & 44 & 66 & 44 \\
\hline Rigidity of Hours Index & 60 & 60 & 80 & 60 & 60 & 80 & 60 & 60 & 65 & 52 \\
\hline Difficulty of Firing Index & 40 & 50 & 10 & 70 & 50 & 50 & 50 & 70 & 49 & 45 \\
\hline Rigidity of Employment Index & 46 & 64 & 45 & 77 & 51 & 77 & 61 & 58 & 60 & 47 \\
\hline Nonwage labor cost (\% of salary) & 29.0 & 20.0 & 18.4 & 22.0 & 26.9 & 17.4 & 21.4 & 25.0 & 22.5 & 12.7 \\
\hline $\begin{array}{l}\text { Firing costs (weeks of wages) } \\
\text { Registering Property }\end{array}$ & 35.8 & 33.6 & 48.8 & 86.7 & 31.4 & 31.4 & 37.9 & 35.8 & 42.7 & 71.2 \\
\hline Procedures (number) & 3 & 8 & 6 & 9 & 5 & 5 & 6 & 7 & 6 & 7 \\
\hline Time (days) & 50 & 107 & 32 & 211 & 33 & 49 & 114 & 242 & 105 & 110 \\
\hline $\begin{array}{l}\text { Cost (\% of property value) } \\
\text { Gettıng Creaıt }\end{array}$ & 15.1 & 16.2 & 14.3 & 13.2 & 20.7 & 14.0 & 18.1 & 7.7 & 14.9 & 11.6 \\
\hline Legal Rights Index & 4 & 4 & 3 & 3 & 3 & 3 & 3 & 3 & 3 & 4 \\
\hline Credit Information Index & 1 & 1 & 1 & 1 & 1 & 1 & 1 & 1 & 1 & 1 \\
\hline $\begin{array}{l}\text { Public registry coverage (\% adults) } \\
\text { Protectıng Investors }\end{array}$ & 10.3 & 2.4 & 3.1 & 1.0 & 2.9 & 1.2 & 4.7 & 3.6 & 3.7 & 1.5 \\
\hline Disclosure Index & 5 & 6 & 6 & 0 & 6 & 4 & 4 & 4 & 4 & 4 \\
\hline Director Liability Index & 8 & 5 & 5 & 5 & 5 & 5 & 4 & 3 & 5 & 4 \\
\hline Shareholder Suits Index & 4 & 3 & 3 & 6 & 3 & 5 & 4 & 5 & 4 & 5 \\
\hline $\begin{array}{l}\text { Investor Protection Index } \\
\text { Payıng Taxes }\end{array}$ & 5.7 & 4.7 & 4.7 & 3.7 & 4.7 & 4.7 & 4.0 & 4.0 & 4.5 & 4.7 \\
\hline Payments (number) & 72 & 45 & 71 & 47 & 60 & 44 & 59 & 51 & 56 & 41 \\
\hline Time (hours) & 270 & 270 & 270 & 208 & 270 & 270 & 696 & 270 & 316 & 336 \\
\hline Profit tax (\%) & 19.7 & 19.8 & 13.6 & 15.5 & 12.0 & 14.5 & 14.9 & 12.7 & 15.3 & 24.2 \\
\hline Labor tax and contributions (\%) & 33.6 & 23.2 & 20.6 & 25.5 & 31.2 & 20.1 & 24.8 & 29.1 & 26.0 & 14.0 \\
\hline Other taxes $(\%)$ & 15.3 & 8.2 & 11.4 & 6.5 & 6.9 & 11.4 & 8.1 & 6.5 & 9.3 & 33.0 \\
\hline $\begin{array}{l}\text { Total tax rate (\% profit) } \\
\text { Trading Across Borders }\end{array}$ & 68.5 & 51.1 & 45.7 & 47.5 & 50.0 & 46.0 & 47.7 & 48.3 & 50.6 & 71.2 \\
\hline Documents for export (number) & 8 & 9 & 9 & 8 & 10 & .. & 6 & 7 & 8 & 8 \\
\hline Time for export (days) & 35 & 69 & 21 & 27 & 66 & .. & 22 & 32 & 39 & 40 \\
\hline Cost to export (US $\$$ per container) & 980 & 1215 & 781 & 1656 & 1752 & .. & 978 & 463 & 1118 & 1561 \\
\hline Documents for import (number) & 11 & 13 & 19 & 9 & 16 & 19 & 10 & 9 & 13 & 12 \\
\hline Time for import (days) & 48 & 66 & 48 & 26 & 61 & 89 & 26 & 41 & 51 & 52 \\
\hline $\begin{array}{l}\text { Cost to import (US\$ per container) } \\
\text { Entorcıng Contracts }\end{array}$ & 1452 & 1700 & 1395 & 1749 & 2680 & 3266 & 1674 & 695 & 1826 & 1947 \\
\hline Procedures (number) & 49 & 41 & 25 & 40 & 28 & 33 & 33 & 37 & 36 & 38 \\
\hline Time (days) & 720 & 446 & 525 & 1140 & 860 & 360 & 780 & 535 & 671 & 581 \\
\hline $\begin{array}{c}\text { Cost (\% of debt) } \\
\text { Closing a Busıness }\end{array}$ & 29.7 & 95.4 & 29.5 & 27.0 & 45.0 & 42.0 & 23.8 & 24.3 & 39.6 & 42.2 \\
\hline Time (years) & 4.0 & 4.0 & 2.2 & No & 3.6 & 5.0 & 3.0 & 3.0 & 3.5 & 3.5 \\
\hline Cost (\% of estate) & 14.5 & 9.0 & 18.0 & No & 18.0 & 18.0 & 7.0 & 14.5 & 14.1 & 20.2 \\
\hline Recovery rate (cents on the dollar) & 23.7 & 26.4 & 33.8 & 0.0 & 23.7 & 14.2 & 31.6 & 27.2 & 22.6 & 17.7 \\
\hline
\end{tabular}

Source: World Bank, Doing Business, 2006.

${ }^{1}$ Simple average. 
Figure 29. CEMAC and WAEMU: Doing Business Indicators, 2006

Ease of Doing Business, 2006

(Rank, best=1 to worst=175)

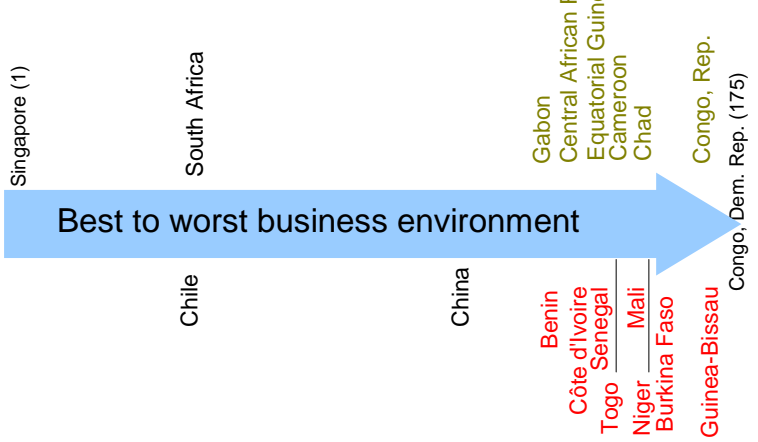

Cost of Starting a Business, 2006

(Percent of income per capita)

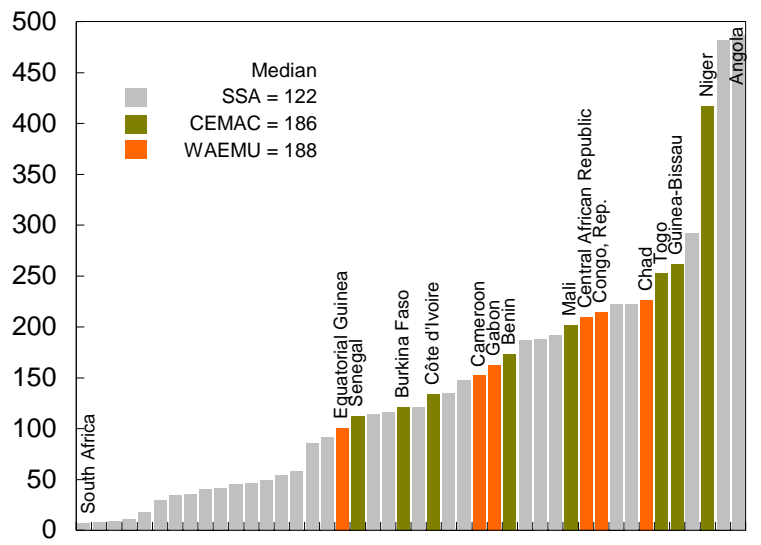

Hiring Cost, 2006

(Percent of salary)

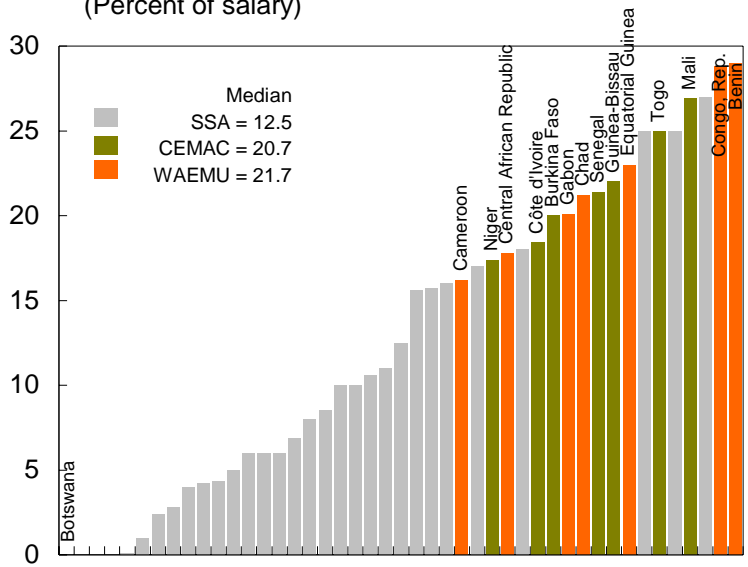

Time for Export, 2006

(Days)

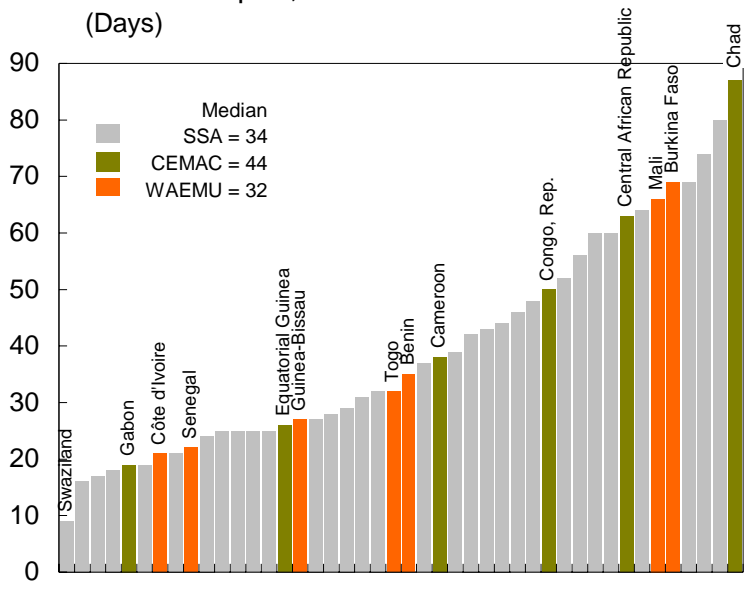

Source: World Bank, Doing Business, 2006.

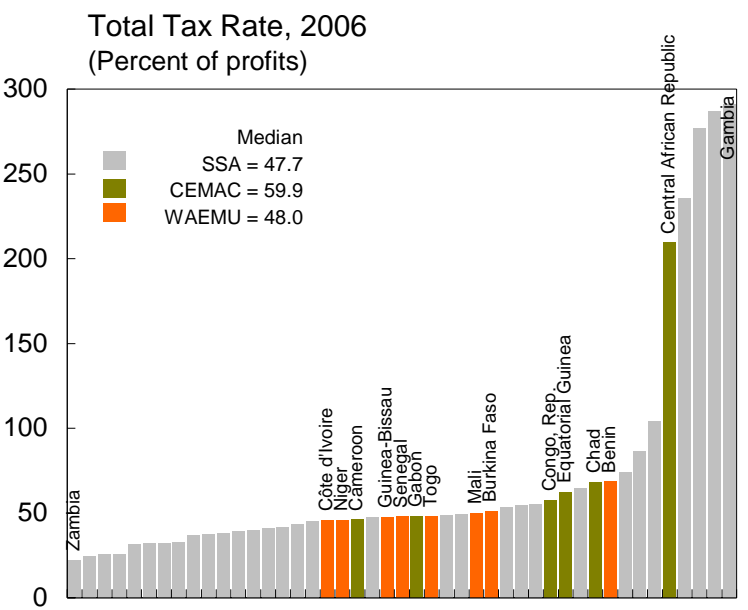

Time for Import, 2006

(Days)

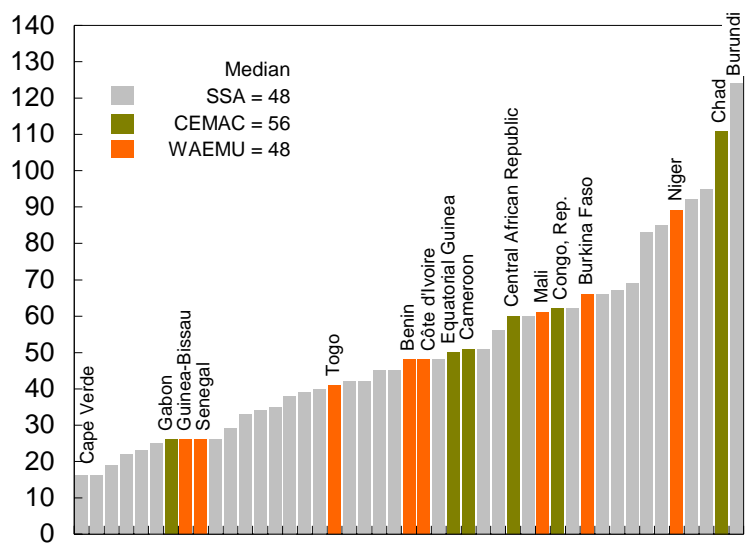


In both WAEMU and CEMAC, the costs of starting a business are higher than in SSA generally or and any other comparator group. The minimum capital required to start a business in a WAEMU country is 2.5 times higher (in income per capita terms) on average than in SSA and registering property is about 30 percent costlier in both WAEMU and CEMAC. Moreover, labor regulations in WAEMU and CEMAC are 20-30 percent more rigid than in SSA; firing costs are almost twice as high in both WAEMU and CEMAC than in SSA as a whole. For investors, disclosure of ownership and financial information is not as satisfactory in the CEMAC as in SSA, though about the same for WAEMU, and it is more difficult and costly to enforce contracts. Finally, closing a business in the CEMAC is about twice as costly and timeconsuming than in SSA, and the recovery rate is extremely low (10 cents on the dollar compared to 18 for SSA). In the WAEMU, time to close a business is longer but the cost is lower than the SSA average, and the recovery rate is about 23 cents, above both the CEMAC and SSA averages.

Starting a business in SSA generally is four to five times more onerous than in a median developing country, and the costs in CEMAC or WAEMU are six to ten times higher. The median cost of hiring relative to salary is about 70 percent above SSA, and most countries in the regions top the highest recruiting costs for SSA. Benin and Congo are the most costly places to hire of all SSA countries. Although CEMAC and WAEMU countries face high hiring costs, they are only 50 percent above the median developing country. The tax burden relative to profits puts CEMAC above WAEMU, which is close to the SSA average. Almost 60 percent of the profits are taken in taxes in CEMAC, and about 48 percent in WAEMU, which is at the SSA median and not far from the median developing country (46 percent). As for the external sector, in 2006 the WAEMU region is again very close to the SSA average, but in CEMAC the total number of days needed to export and import was about 10 more for the median country compared to WAEMU and SSA. The median developing country can place its merchandise in just 26 days, in WAEMU a country needs 32 days, and in CEMAC 44 days. Imports reach their destination in the median developing country in 34 days, but the process takes 48 days in WAEMU and 56 days in CEMAC.

In summary, the profitability of exports improved in the CEMAC thanks to rising oil prices but has lately declined somewhat in the WAEMU. Survey-based indicators of the business environment reveal structural impediments to developing a competitive private sector in both regions.

\section{B. Governance}

Poor governance and weak institutions can undermine competitiveness by imposing significant direct and indirect costs on the businesses environment and the cost of doing business. The World Bank's Worldwide Governance Indicators (WGI) database covers six dimensions of governance in 213 countries for 1996-2006. The indicators are constructed by aggregating surveys and indicators, and the dimensions covered are voice and accountability, political 
stability and absence of violence, government effectiveness, regulatory quality, rule of law, and control of corruption. ${ }^{22}$

Both WAEMU and CEMAC countries tend to rank below average on important dimensions of governance compared to other countries at a similar level of development (Figure 30). However, there has been progress in recent years, and in some cases averages may mask country improvements. For example, Senegal is cited in the 2006 WGI report as one of six African countries that have made progress in improving governance and curbing corruption. ${ }^{23}$

Fewer than 18 percent of the countries in the WGI sample had lower scores on the governance indicators generally than the CEMAC average in 2006. CEMAC countries perform worst on the government effectiveness and control of corruption components, with on average less than 13 percent of all countries ranking below them. In terms of the other components, CEMAC countries rank between the 14th and 30th percentiles, with relatively higher rankings on political stability. There is considerable variation between countries: aside from Gabon, which typically ranks highest in the area in all components (e.g., in the 54th percentile for political stability), the other countries rank very low on at least one component (e.g., CAR is in the 3rd percentile in government effectiveness, Equatorial Guinea in the 5th in voice and accountability, Chad in the 10th in political stability, and Congo in the 5th on the rule of law).

WAEMU countries on average rank better than the CEMAC countries as about 30 percent of the countries surveyed ranked worse than the WAEMU average. On average WAEMU countries are at about the 40th percentile in voice and accountability, but only in the 24th in government effectiveness. Excluding Côte d'Ivoire and Guinea Bissau from the averages improves the rankings by as much as 10 percentage points. There are again substantial variations. Benin, Senegal, Mali, and Burkina Faso are performing relatively better, and Côte d'Ivoire and Guinea Bissau relatively worse. Mali, for instance, ranks at the 60th percentile in voice and accountability and 51st in the rule of law. Senegal ranks at the 50th percentile on government effectiveness and 43rd on regulatory quality. Benin is in the 58th percentile in political stability and Burkina in the 58th in the control of corruption. As expected, Côte d'Ivoire and Guinea Bissau are doing badly particularly in political stability (Côte d'Ivoire at the 1st percentile); rule of law (Côte d'Ivoire at the 4th percentile); control of corruption (Côte d'Ivoire at the 6th percentile); and government effectiveness (Guinea-Bissau at the 4th percentile).

In summary, countries in the two regions tend to rank below average on important dimensions of governance, such as government effectiveness, regulatory quality, the rule of law, and control of corruption, compared to other countries at a similar level of development.

\footnotetext{
${ }^{22}$ The data and methodology used to construct the indicators are described in Kaufmann, Kraay, and Mastruzzi (2006). Compared with the Transparency International (TI) Corruption Perceptions index, the WGI indicators rely on a broader set of sources and cover about twice as many countries. WGI data have smaller margins of error than the TI index.

${ }^{23}$ The other five are Botswana, Ghana, Sierra Leone, Mozambique, and Liberia.
} 
Figure 30. Governance Indicators, 2005
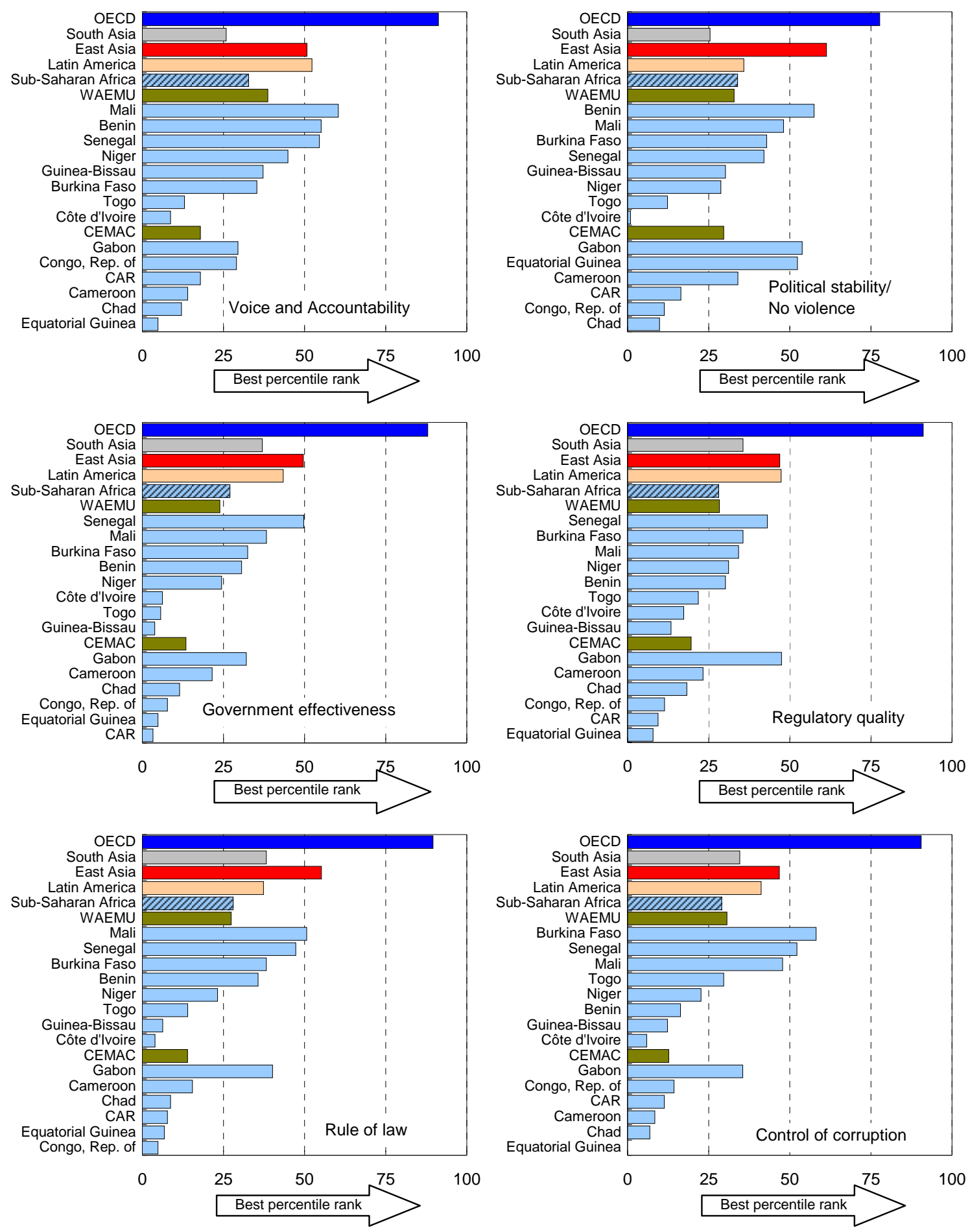

Source: World Bank, Governance Indicators, 2006. 


\section{Technology and Physical and Human Capital}

Technology and capital, both physical and human, are policy inputs that can raise productivity and competitiveness. Perhaps the most widely used determinant of productivity is technology and innovation. This includes anything new about the means of producing goods and services, including ideas, techniques, products, machines, and forms of organization; in a sense, changes in technology are the only source of permanent increases in productivity. In addition, the capital infrastructure in a country affects competitiveness and performance in a number of ways: it can increase productivity, reduce costs, and facilitate trade and other economic transactions. Finally, human capital, especially education and health, is important for economic performance and can be considered part of the country's infrastructure in competitiveness terms.

Infrastructure and technology indicators show some improvements over SSA averages (Figure 31). For both WAEMU and CEMAC physical infrastructure as measured by the percentage of paved roads improved in 2000-05 compared to 1990-95. However, at about half the SSA

Figure 31. Infrastructure and Technology Indicators
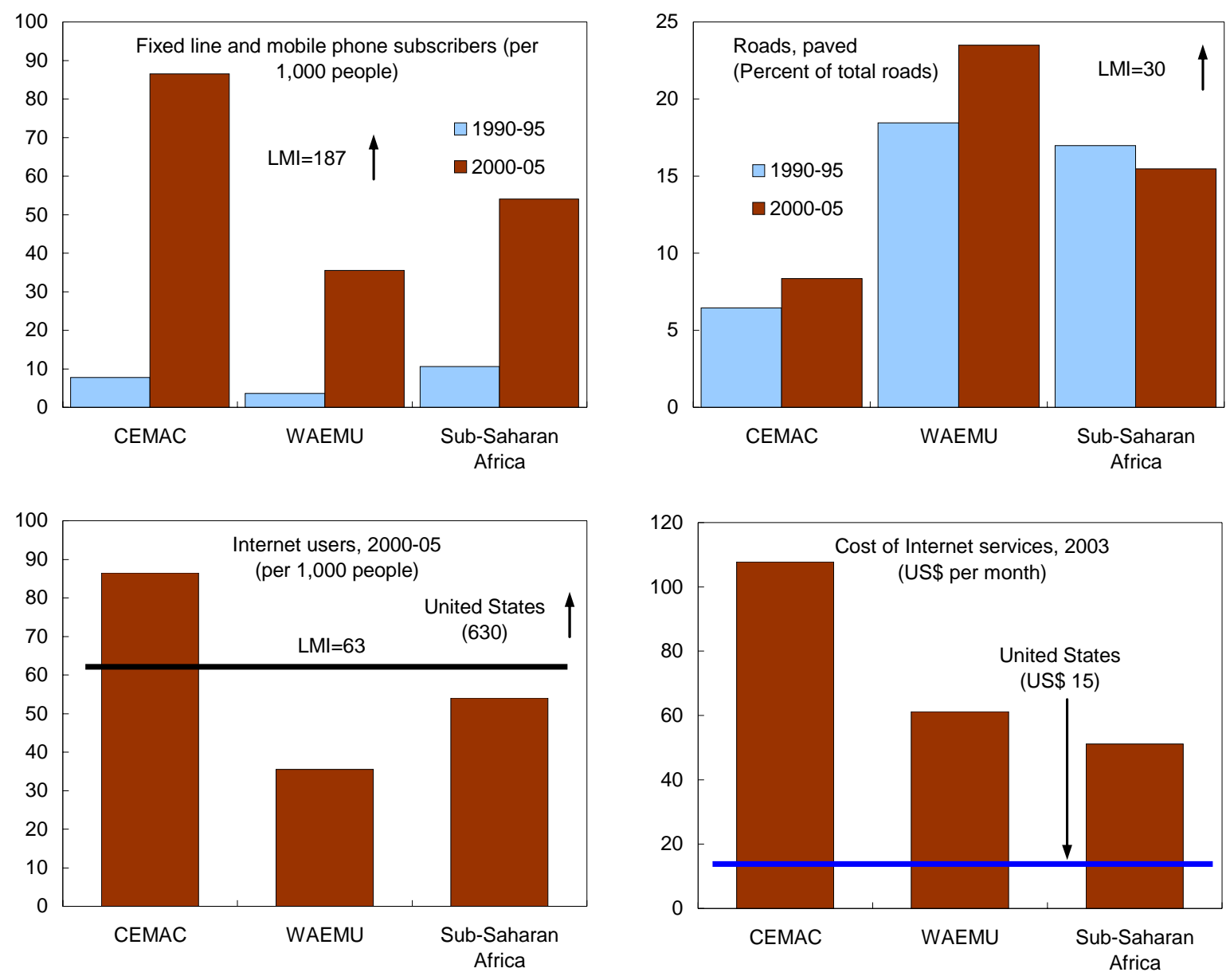

Source: World Bank, World Development Indicators, 2006. 
average infrastructure in CEMAC is particularly poor, though in WAEMU it is about 50 percent higher than the SSA average and compares favorably with Latin America (27 percent) and the general LMI country average (30 percent). Improvements in the WAEMU are likely to continue in light of the recent Regional Economic Plan (REP), an ambitious program designed at accelerating regional growth; 80 percent of REP resources are allocated to road projects. ${ }^{24}$

Using mobile phone subscriptions and internet usage as a proxy for technology suggests that CEMAC performs above both the WAEMU and SSA averages. Yet average CEMAC mobile subscriptions for 2000-05 are below the average for LMI countries (187) and Latin America (318). Internet usage in CEMAC is above the average for lower- and middle-income countries (63) but below the Latin America average (115), and it is very expensive: monthly costs services are almost two and a half times higher than the SSA average and about four times higher than the lower-middle income country average.

Selected human capital indicators for WAEMU and CEMAC point to deficiencies that in some cases are staggering (Figure 32). At about 50 years, life expectancy in WAEMU is higher than in CEMAC, which is marginally better than in SSA; but more worryingly, in both CEMAC and SSA life expectancies declined in 2000-05 compared to 1990-95. The 2000-05 WAEMU and CEMAC rates are strikingly lower than for other developing country groups, such as Latin America (72 years), East Asia and Pacific (70), and South Asia (63). Infant mortality rates have improved in WAEMU to about the SSA rates $(102$ per 1,000$)$ but marginally worsened in CEMAC in 2000-05. The rates are much higher than for Latin America (27), East Asia and Pacific (29), and South Asia (66). The education and health expenditures-to-GDP ratio is below SSA levels for both WAEMU and CEMAC. At about 4 to 5 percent of GDP for health and 2.5 to 3 percent for education in 2000-05, these will not be sufficient for these countries to attain the Millennium Development Goals; though primary education completion rates have improved for both WAEMU (35 percent) and CEMAC (521 percent), they are below the SSA level , which, in turn, is lower than the LMI group (86 percent) Latin America (97 percent) and South Asia (82 percent). Finally, HIV prevalence in 2000-05 was below SSA levels in both WAEMU (2 percent of the population) and CEMAC (6 percent). Nevertheless, these rates are much higher than any other developing country group considered; the lower- and middle-income country average was 1.2 percent and the East Asia and Pacific average was 0.2 percent.

In summary, while selected physical capital indicators point to improvement, particularly for the CEMAC, the two regions are seriously deficient according to human capital indicators.

\footnotetext{
${ }^{24}$ The REP calls for regional priority spending to be scaled up by about 2,900 billion CFAF, about 11 percent of the region's 2006 GDP.
} 
Figure 32. Human Capital Indicators
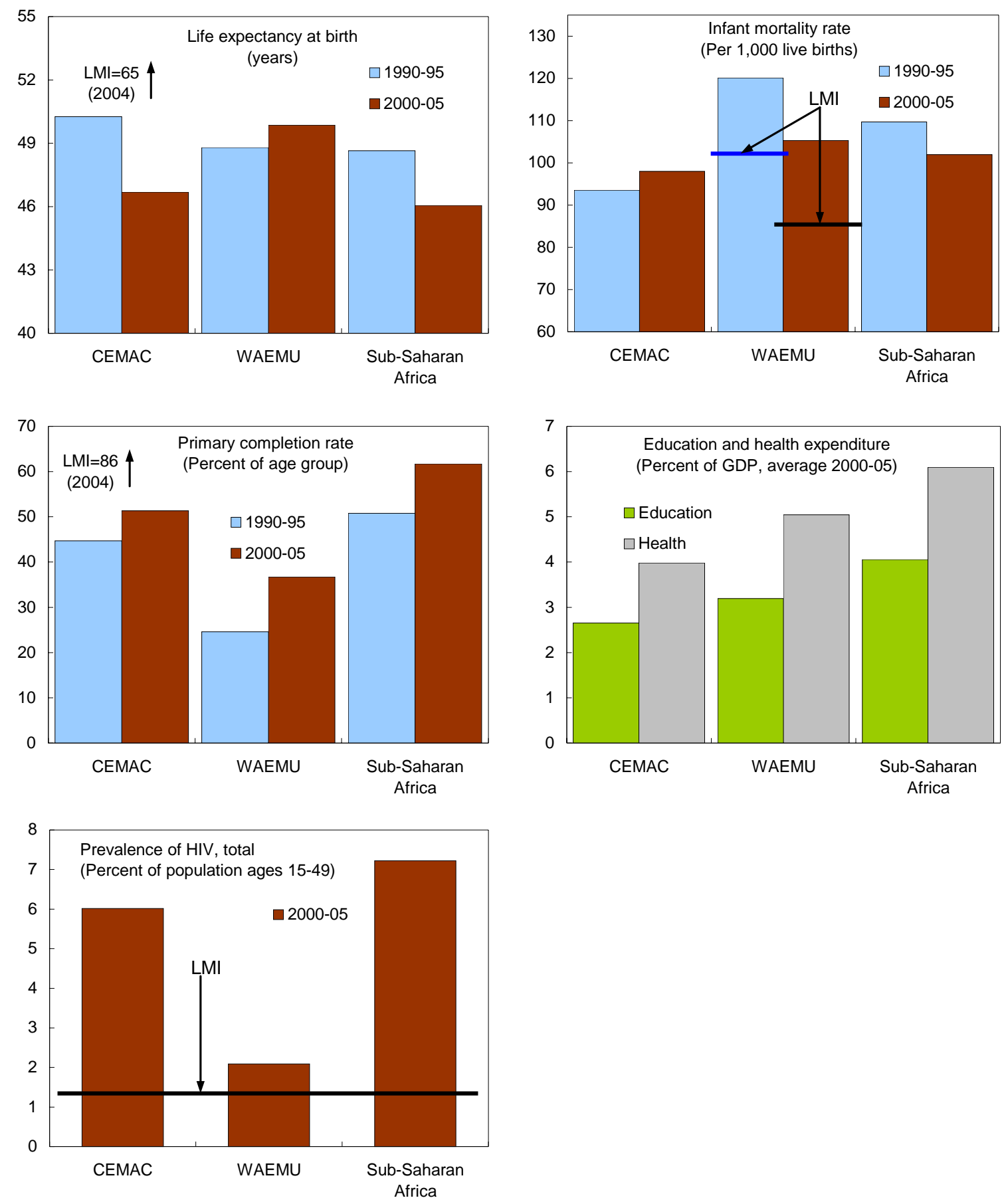

Source: World Bank, World Development Indicators, 2006.

\section{CONCLUSION}

The multifaceted approach to competitiveness proposed in the introduction was applied to examine recent developments in competitiveness in the WAEMU and CEMAC regions. The 
approach views competitiveness in a context of framework and goes beyond simply presenting conventional indicators of competitiveness. It also views competitiveness as a strategy where the ultimate goals are sustainable growth and improvements in the quality of life. Key elements of this strategy are the two linked components environment and policy, which are each analyzed in terms of quantifiable determinants.

The results of our analysis can be summarized as follows. First, improvements in GDP growth rates have for the most part failed to translate into improvements in quality of life indicators. Second, the environment indicators of competitiveness show a mixed picture. On the one hand, REER measures indicate clear appreciation following the 1994 devaluation; however, the extent of the appreciation depends on which indicator is used. The appreciation is less pronounced for the labor-cost REER compared to the CPI, and most pronounced using internal real exchange rate measures. On the other hand, export patterns and market shares show some improvements in competitiveness. In spite of the real appreciation, the terms of trade and export profitability in the CEMAC have recently improved - although the improvements have failed to translate into increased export market shares. This is partly because the recent real appreciation was driven mostly by nominal exchange rate changes and has so far failed to translate into price and wage increases. In addition, the overall terms of trade and profitability improvements have been driven by oil price and volume increases; for non-oil exports terms of trade and profitability have been declining since the late 1990s. Export profitability in the WAEMU region has remained roughly constant since 1994. Third, the policy indicators of competitiveness suggest structural rigidities in business climate and governance indicators, as well as significant challenges in improving human and physical capital in comparison to other pier groups WAEMU and CEMAC face significant challenges.

We summarize the competitiveness challenges CEMAC and WAEMU face in Figures 33 and 34. Using representative indicators already discussed, we plot WAEMU and CEMAC indicators against those for SSA and for LMI countries: the further the distance away from the group toward the center, the worse the competitiveness problems. Clearly, both WAEMU and CEMAC fare significantly worse on the majority of the measures, lagging behind both the SSA average and the LMI country average.
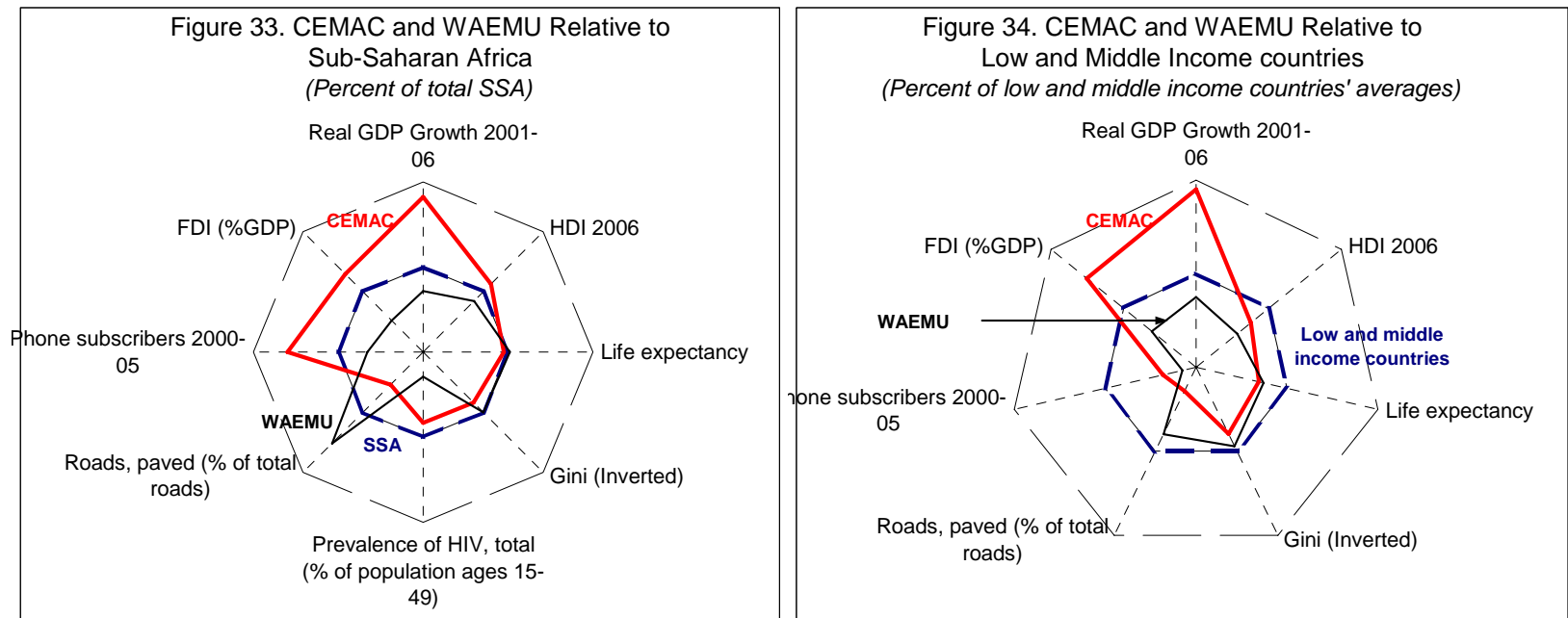
Building competitiveness in order to raise growth and improve the quality of life needs to be a major objective of WAEMU and CEMAC and each of their member countries. Priorities should include structural reforms to boost labor productivity, reduce excessive factor costs, and diversify the base of production and exports of the economies; reduction of factor costs by improved access to new technologies; regional integration programs, notably in road infrastructure, telecommunications and energy, and other areas facilitating interregional trade; and creating the right conditions for an increase in domestic and foreign private investment in all sectors of the economic (especially in the non-oil sector for CEMAC), beginning with reforming the legal and regulatory system, governance, and the business environment. 


\section{Appendix A \\ Calculation of the Internal Real Exchange Rate}

The internal real exchange rate (IRER) is calculated as the ratio of the domestic prices of nontradable to those of tradable goods. To categorize the consumption bundle into tradable and nontradable goods, we use two proxies described in the literature.

\section{First proxy: IRER}

Using the definition of IRER, ${ }^{25}$

$$
\operatorname{IRER}=P_{N T} / P_{T}
$$

Also, the consumer price index (CPI) can be defined as a weighted average of the prices of tradable and nontradable goods. Let $z$ be the share of tradable goods in the CPI basket. Then,

$$
C P I=\left(P_{T}\right)^{z}\left(P_{N T}\right)^{1-z}
$$

Reorganizing (2) and substituting (1), the IRER can be expressed as

$$
I R E R_{1}=\left(C P I / P_{T}\right)^{1 /(1-z)}
$$

Import prices (from the import price index) were used as a proxy for prices of tradable goods, and the share of imported consumption goods in total private consumption was used as a proxy for $z$.

\section{Second proxy: IRER 2}

The second proxy was based on the three-good model of Devarajan, Lewis, and Robinson (1993). ${ }^{26}$ The model categorizes the economy as producing a domestic good and an exported good. Aggregate income is given by:

$$
p_{y} Y=p_{d} D+p_{x} X
$$

\footnotetext{
${ }^{25}$ The same methodology was used in IMF Occasional Paper No. 170 by Hernández-Catá and others (1998) and is also discussed in detail in Hinkle and Nsengiyumva (1997).

${ }^{26}$ The domestically produced good, the imported consumption good, and the export good.
} 
where $p_{y}$, is the GDP deflator, $p_{d}$ is the price of the domestically produced good, $p_{x}$ is the price of the export good, $Y$ is total output, $D$ is output of the domestically produced good, and $\mathrm{X}$ is the output of the exported good (all in real terms).

Dividing (4) by $Y$ and denoting the share of exports $X / Y$ as $S_{x}$ yields

$$
p_{y}-p_{x} S_{x}=p_{d} D / Y
$$

Rearranging (5) and letting $\left(1-S_{x}\right)=D / Y$ yields

$$
p_{d}=\left(p_{y}-S_{x} p_{x}\right) /\left(1-S_{x}\right)
$$

IRER $_{2}$ can then be calculated using the standard definition $\left(P_{N T} / P_{T}\right)$ and using import prices as a proxy for the price of tradable goods:

$$
\operatorname{IRER}_{2}=\left[\left(p_{y}-S_{x} p_{x}\right) /\left(1-S_{x}\right)\right] / P_{T} .
$$




\section{Appendix B \\ Calculation of the Unified Regional Effective Exchange Rates (UREERs)}

The calculation of the UREERs for CEMAC and WAEMU follows the standard method used by the IMF to compute monthly indices at the country level and the approach applied by the European Central Bank to obtain the effective exchange rate of the Euro. ${ }^{27}$ The key feature of the UREER construction is the correct calculation of trade weights for each of the two regions compared to their partners, so intraregional trade is taken out to avoid biasing the results. Information on exchange rates and prices are from IMF, International Financial Statistics, and on international trade from IMF, Direction of Trade Statistics. The calculation of the UREERs proceeds as follows:

1. Total merchandise exports and imports are obtained for each of the CEMAC and WAEMU countries to calculate flows net of intra-regional trade for 2000-04.

2. Weights are calculated based on total merchandise exports and imports, for 2000-04 (see Table 1). For CEMAC the main partners are the United States (28 percent), France (20 percent), other Euro-area countries (24 percent), China (9 percent) and, others (19 percent). WAEMU trades mainly with France (26 percent), other Euro-area countries (26 percent), Nigeria (10 percent), the United States (6 percent), and others (32 percent). CEMAC trade is more concentrated in a few countries; WAEMU has a longer list of partners and trades more with other African countries. ${ }^{28}$

3. A common deflator for each region is constructed based on national consumer prices weighted by the domestic product at purchasing power parity (GDP_PPP). The average GDP_PPP for 2000-04 produces the country's relative weight in the aggregated CPI inflation of the monetary union. The domestic CPI inflation for the individual partner countries is weighted by the same trade weights used in the UREER calculation.

4. To calculate the URNEERs, geometric weighted averages of the third-country exchange rates relative to the monthly average of the CFA franc exchange rate are obtained. The URREERs are based on the URNEERs and the national consumer prices. The regional CPI is the weighted average of the CPIs of the countries in the region, with the weights based on the GDP_PPP for 2000-04.

Specifically, the following formula was applied for the URNEER:

\footnotetext{
27 See Buldorini, Makrydakis, and Thimann (2002).

${ }^{28}$ For CEMAC, 52 countries accounted for more than 82 percent of total trade. For WAEMU, 32 countries accounted for more than 75 percent of the region's exports and imports.
} 


$$
\operatorname{URNEER}_{j}=\frac{e_{j}}{\operatorname{Exp}\left(\sum_{i=1}^{n} w_{j i} * \ln \left(e_{i}\right)\right)}
$$

where $j$ is the CEMAC or WAEMU, $i$ is the partner country, $e$ is the exchange rate in local currency for US dollars, and $w_{j i}$ is the weight of country $i$ in total trade of the region $j$ (sum of the weights is 1).

The URREERs is obtained from:

$$
\operatorname{URREER}_{j}=\frac{C P I_{j} * e_{j}}{\operatorname{Exp}\left(\sum_{i=1}^{n} w_{j i} * \ln \left(C P I_{i} * e_{i}\right)\right)}
$$

where $C P I$ refers to the consumer price index of either the region $j$ or the country $i$

To compare indices it is also possible to obtain measures of international price competitiveness for subgroups of trade partners. Specifically, UREERs were calculated in terms of the European Union and the rest of SSA. In those cases, relevant countries were listed and the weights renormalized to add up to one (100 percent).

Table 1. CEMAC and WAEMU Trade Weights, 2000-04

\begin{tabular}{lrrrr}
\hline \multicolumn{1}{c}{ CEMAC } & & & \multicolumn{2}{c}{ WAEMU } \\
\cline { 1 - 1 } United States & 28.4 & & France & 26.2 \\
France & 19.7 & & Nigeria & 9.8 \\
China,P.R.: Mainland & 9.3 & & Netherlands & 7.9 \\
Spain & 9.2 & & United States & 5.8 \\
Italy & 6.0 & & Italy & 4.9 \\
Netherlands & 3.5 & & Spain & 4.2 \\
United Kingdom & 2.6 & & India & 4.1 \\
Korea & 2.5 & & Germany & 3.7 \\
Germany & 2.2 & & China & 3.6 \\
Nigeria & 2.1 & & Belgium & 3.5 \\
Belgium & 1.9 & & United Kingdom & 3.0 \\
Japan & 1.9 & & Thailand & 2.7 \\
Canada & 1.7 & & Ghana & 2.1 \\
Portugal & 1.4 & Japan & 2.0 \\
Côte d'Ivoire & 1.1 & Gabon & 1.7 \\
Other & 6.6 & Other & 14.7 \\
\hline Source: IMF, Direction & of & Trade & Statistics. &
\end{tabular}




\section{References}

Abdih, Y., and C. Tsangarides, 2006, “FEER for the CFA Franc,” IMF Working Paper No. 06/236 (Washington: International Monetary Fund).

Buldorini, L. S. Makrydakis, and C. Thimann, 2002, “The Effective Exchange Rates of the Euro”, ECB Occasional Paper Series No. 2 (Frankfurt: European Central Bank).

Cashin P., L. Cespedes, and R. Sahay, 2004, “Commodity Currencies and the Real Exchange Rate,” Journal of Development Economics, Vol. 75, pp. 239-68.

Cockburn, J., E. Siggel, M. Coulibaly, and S. Vézina, 1998, “Measuring Competitiveness and its Sources: The Case of Mali’s Manufacturing Sector”.

Di Bella, G., M. Lewis, and A. Martin “Assessing Competitiveness and Real Exchange Rate Misalignments in Low-Income Countries,” draft IMF Working Paper.

Durand, M., J. Simon, and C. Webb, 1992, “OECD’s Indicators of International Trade and Competitiveness,” OECD Economic Department Working Papers, No.120 (Paris: Organization for Economic Cooperation and Development), available at http://www.oecd.org/dataoecd/19/56/28740598.pdf.

Edwards, S., 1989, Real Exchange Rates, Devaluation and Adjustment: Exchange Rate Policy in Developing Countries (Cambridge: MIT Press).

Heritage Foundation, 2003, “Index of Economic Freedom,” http://www.heritage.org.

Hernandez-Cata, E., and others, 1998, “The West African Economic and Monetary Union, Recent Developments and Policy Issues,” IMF Occasional Paper No. 170 (Washington: IMF).

Hinkle, Lawrence, and Peter J. Montiel, 1999, Exchange Rate Misalignment: Concepts and Measurement for Developing Countries (Washington: World Bank).

International Labor Organization, "Key Indicators of the Labour (KILM): Unit labor costs, productivity and international competitiveness" http://www.ilo.org/public/english/employment/strat/kilm/

International Management Development Institute, World Competitiveness Yearbook (Lausanne: Switzerland), http://www.imd.ch/research/publications/.

International Monetary Fund, 2005, “Central African Economic and Monetary Community (CEMAC): Selected Issues,” IMF Country Report No. 05/390 (Washington: IMF). 
Irish National Competitiveness Council, Annual Competitiveness Report 2006 (Dublin: Ireland) http://www.forfas.ie/ncc/.

Johansen, S., 1995, Likelihood-based Inference in Cointegrated Vector Autoregressive Models (United Kingdom: Oxford University Press).

Kaufmann, D., A. Kraay, and P. Zoido-Lobatón, 1999, “Aggregating Governance Indicators,” World Bank Policy Research Working Paper No. 2195 (Washington: World Bank).

Kaufmann, D., A. Kraay, and M. Mastruzzi, 2004, “Governance Matters III: Governance Indicators for 1996-2002” (Washington: World Bank), available at http://www.worldbank.org/wbi/governance/govdata2002.

Lipschitz, L., and D. McDonald, 1991, "Real Exchange Rates and Competitiveness: a Clarification of Concepts, and Some Measurements for Europe,” IMF Working Paper 91/25 (Washington: International Monetary Fund).

Marsh, I. W., and S.P. Tokarick, 1994, "Competitiveness Indicators-A Theoretical and Empirical Assessment,” IMF Working Papers 94/29 (Washington: International Monetary Fund).

Murgasova, Z., 2004, “Assessing Competitiveness,” in Republic of Poland: Selected Issues, IMF Country Report No. 04/197 (Washington: International Monetary Fund).

Organization for Economic Cooperation and Development, 1992, Technology and the Economy: The Key Relationships, (Paris: OECD).

Ramirez G. and C. Tsangarides, 2007, "Calculation of the Unified Regional Effective Exchange Rates for the CFA franc Region”, mimeo.

United Nations Human Development Report 2007 http://hdr.undp.org/

World Economic Forum 2007, Global Competitiveness Report (Geneva: Switzerland) http://www.weforum.org/en/index.htm.

World Economic Forum 2007, Africa Competitiveness Report (Geneva: Switzerland) http://www.weforum.org/en/events/WorldEconomicForumonAfrica2007/index.htm

World Bank, Doing Business Project, (Washington: World Bank) http://rru.worldbank.org/DoingBusiness/.

Zanello, A., and D. Desruelle, 1997, “A Primer on the IMF’s Information Notice System,” IMF Working Paper No. 97/71 (Washington: International Monetary Fund). 